This is an Accepted Manuscript of an article published by Pion Ltd. in Environment and Planning A, available online: $\underline{\text { http://www.envplan.com/abstract.cgi } ? \text { id }=a 46265}$ or http://dx.doi.org/10.1068/a46265.

This is Özlem Onaran and Giorgos Galanis, 2014. The definitive, peer-reviewed and edited version of this article is published in Environment and Planning A, volume 46, issue 10, pages 2489-2513, 2014, doi:10.1068/a46265.

\title{
Income distribution and growth: A global model
}

Forthcoming in Environment and Planning A 2014

Özlem Onaran*

Giorgos Galanis**

* Corresponding author, Professor of Workforce and Economic Development, University of

Greenwich, Greenwich SE10 9LS, London , UK; e-mail: o.onaran@gre.ac.uk, Phone: 02083318519

** PhD Candidate, University of Warwick, Coventry, CV4 7AL, UK, email: galanix@gmail.com

Acknowledgements: This paper has received research funding from the International Labour Office. We are grateful to three anonymous referees, Engelbert Stockhammer, Servaas Storm, Amitava Dutt, Sangheon Lee, Patrick Belser, Marc Lavoie, Gerald Epstein, and Yiannis Dafermos for helpful comments, to Susan Pashkoff for careful language editing, and to Matthieu Charpe, Ricardo Molero Simarro, Uma Rani Amara, Rayaproulu Nagaraj, Juan Graña, Joana Chapa, Araceli Ortega Diaz, Morne Oosthuizen, Claudio Roberto Amitrano, and Kazutoshi Chatani, and Byung-Hee Lee for their valuable support regarding data. All remaining errors are ours. 


\title{
Income distribution and growth: A global model
}

\begin{abstract}
This article estimates the effects of a change in the wage share on growth at global level in the G20 countries. A decrease in the wage share in isolation leads to lower growth in the euro area, Germany, France, Italy, UK, US, Japan, Turkey, and Korea, whereas it stimulates growth in Canada, Australia, Argentina, Mexico, China, India, and South Africa. However, a simultaneous decline in the wage share in all these countries leads to a decline in global growth. Furthermore, Canada, Argentina, Mexico, and India also experience negative effects on growth when they decrease their wage-share along with their trading partners. The results indicate that the global decline in labour share has had significant negative effects on growth.
\end{abstract}

Key words: wage share, growth, global multiplier, consumption, investment, exports, imports, G20, developed and developing countries 


\section{Introduction}

There has been a significant decline in the share of wages in GDP in both the developed and developing countries following the 1980s. The reasons for the fall in the wage shares have recently been the subject of a growing literature trying to pin down the effects of technology, globalization, financialisation, changes in the bargaining power of labour, and welfare state retrenchment (IMF, 2007; EC, 2007; ILO, 2011; Rodrik, 1997; Stockhammer, 2013). This article aims at estimating the effects of this change in the primary functional income distribution between wages and profits on growth at a global level.

During this period there has been also an increase in personal income inequality. Daudey and Garcia-Penalosa (2007) and Jäntti (1997) show that the rise of personal income inequality is related to changes in the wage share. Wolff and Zacharias (2007) find that the increase in inter-class inequality was the fundamental cause of the increase in personal income inequality. The distribution of personal income depends on the distribution of labour and capital endowments, and the way in which aggregate output is shared between the two. If the distribution of capital is more unequal than that of labour, a decrease in the labour share would increase personal income inequality (Daudey and Garcia-Penalosa, 2007; Dafermos and Papatheodorou, 2011). Atkinson (2009) argues that the analysis of functional income distribution is important to understand personal income inequality as well as to address issues of social justice.

The decline in the wage share and rise in personal income inequality has accompanied a poor performance in terms of growth in most countries. The relation between personal income inequality and growth has been a field of ongoing controversy (Barro, 2000). Early work by Kuznets (1955) and Kaldor (1956) argues that higher inequality would generate higher savings, more investment and thus higher growth in the early stages of development but in the later stages trickle down effects result in higher per capita income and lower inequality. In support of the thesis that inequality fosters growth, Mirrlees (1971) emphasizes the negative effects of redistribution through taxation on the 
incentives to work. Aghion et.al. (1999) suggest that inequality can lead to a higher concentration of wealth that could overcome problems of poorly functioning credit markets. However, competing theories indicate various channels through which inequality can impede growth. Galor and Zeira (1993) highlight the negative effects of credit market imperfections on human capital accumulation and show that richer economies are more equal than poorer ones. Alesina and Rodrik (1994) and Persson and Tabellini (1994) argue that greater inequality increases public support for redistribution, which leads to higher tax rates on capital, discourages investment and hinders growth. Alesina and Perotti (1996) find that inequality increases political instability and uncertainty, and impede investments.

This article analyses the effects of increasing inequality on growth focusing on functional income distribution, and its effects on demand. We use a Post-Keynesian/Post-Kaleckian theoretical framework (Dutt, 1984; Blecker, 1989; Bhaduri and Marglin, 1990). The contribution of this framework to the research on inequality and growth is to bring in the role of demand in determining growth in economies operating below full employment, and to show the role of wages as a source of demand, and not just a component of cost. With regards to the effects of distribution on demand, consumption is expected to decrease when the wage share decreases since the marginal propensity to consume out of capital income is lower than that out of wage income. A higher profit share is expected to stimulate investment. Finally, net exports will depend negatively on unit labour costs, which are closely related to the wage share. Thus, the total effect of the decrease in the wage share on demand depends on the relative size of the effects on consumption, investment and net exports. If the total effect is negative, the demand regime is called wage-led; otherwise the regime is profit-led. ${ }^{1}$

\footnotetext{
${ }^{1}$ The rise in personal income inequality is also expected to have a negative effect on consumption, since the marginal propensity to consume out of high income is lower than that out of low income. The advantage of working with functional income distribution instead of personal income is that the same variable, wage share, has an effect on not just consumption but also investment and net exports, and aggregating the effects of inequality on demand becomes feasible.
} 
The Post-Keynesian models show that the relationship between the wage share and growth is an empirical matter, which depends on the structural characteristics of the economy. This is in striking contrast to mainstream economic policy -e.g. the European Commission (2006) argues that wage moderation, i.e. real wage growth below productivity growth, is the key to preserve growth and jobs in a competitive global economy.

The theoretical novelty of this article is that it goes beyond an isolated single country as the unit of analysis and develops a global model. What happens to global demand when there is a simultaneous decline in the wage share as has been the case in the post-1980s period? To the best of our knowledge, this article is the first in the literature to develop and estimate a model of the global effects of changes in income distribution.

The second contribution is the inclusion of the developing countries. Most of the previous empirical work on the effects of functional income distribution on growth has focused on developed countries (e.g., Onaran, et al, 2011; Stockhammer, et al, 2011; Stockhammer, et al, 2009; Hein and Vogel, 2008; Naastepad and Storm, 2007; Bowles and Boyer, 1995) with only few exceptions on developing countries (Molero Simarro, 2011 and Wang, 2009; Jetin and Kurt, 2011; Onaran and Stockhammer, 2005).

We first estimate the effect of the wage share on each component of private demand (consumption, investment, and net exports) in the major developed and developing countries; these constitute more than $80 \%$ of the global GDP. Next, we calculate the global effects based on the responses of each country to changes not only in domestic income distribution but also to trade partners' wage share; this in turn affects the import prices and foreign demand for each country.

The rest of the article is organized as follows: section two discusses data and stylized facts. Section three presents the model. Sections four and five discuss the estimation methodology and the results. Section six concludes.

\section{Data and stylized facts}


We focus on the sixteen developed and developing economies, which are members of G20 and have wage share data for a sufficiently long time period: Euro area (12 West European Member States), Germany, France, Italy, UK, US, Japan, Canada, Australia, Turkey, Mexico, South Korea, Argentina, China, India, and South Africa.

Appendix A describes the data sources. The estimation period is 1960-2007 for the developed countries, and 1970-2007 for the developing countries (1978-2007 for China). The period after the 2008 crisis are excluded, since it would be impossible to test for possible structural breaks with only few observations.

C, I, X, M, Y, W and R are consumption expenditures, private investment expenditures, exports, imports, GDP (at market prices), wages and profits respectively, all in real terms.

Wages are adjusted labour compensation, calculated as real compensation per employee multiplied by total employment. ${ }^{2}$ In the national accounts, all income of the self-employed are classified as operating surplus. Since part of this is a return to the labour of the self-employed, the unadjusted labour compensation underestimates the labour income. This is a particular problem for the developing countries with high numbers of self-employed workers in the informal economy. Profit is also adjusted gross operating surplus, calculated as GDP at factor cost minus adjusted labour compensation. Profit share, $\pi$, is adjusted gross operating surplus as a ratio to GDP at factor cost, $\mathrm{Y}_{\mathrm{f}}$. Wage share, ws, is $1-\pi$.

One issue with the adjustment in the developing countries is that the wages of the selfemployed in the informal economy would be significantly lower than the average formal wage. However, ignoring the labour income of the self-employed would mean a serious underestimation of the labour income.

${ }^{2}$ For China and India mixed methodologies are used. 
Figure 1 shows the indices of the adjusted wage share. There is a secular decline in the wage share in all countries starting from late 1970s or early 1980s onwards. The fall is slightly lower in the US and UK, which may be related to the increase in managerial wages.

\section{$<$ Figure $1>$}

The developing world have experienced stronger declines in the wage share, particularly during the debt crisis, the initial phases of structural adjustment and the currency crises of the 1990s and 2000s. Even in Korea, the increase in the wage share from mid-1980s onwards was reversed by the crisis in 1997. In China the improvement in the wage share in the 1980s was reversed in 1990.

Table B.1 in the Appendix shows the average growth rates in GDP. In the developed countries, the decline in the wage share was associated with a weaker growth. Similarly, the developing countries in the post-1980s period, with the exception of China and India, have lower growth rates as compared to the 1970s.

\section{A global model}

We model the effects of the changes in the profit share on growth by means of analyzing the country level effects on private demand, i.e. consumption, investment, exports, and imports, as well as the global interactions resulting from the effects of a change in the profit share of other countries.

Consumption, C, is modelled as a function of adjusted profits, R, and adjusted wages, W:

$$
C=C_{o}+C_{r} R+c_{w} W
$$

We calculate the marginal effect of a change in the profit share on $\mathrm{C}$ by multiplying the estimated coefficients of $\mathrm{R}$ and $\mathrm{W}$ by $\mathrm{C} / \mathrm{R}$ and $\mathrm{C} / \mathrm{W}$ (at the mean of our sample) respectively:

$$
\frac{\partial(C / Y)}{\partial(R / Y)}=c_{R} \frac{C}{R}-c_{W} \frac{C}{W}
$$


This is equivalent to the difference in marginal propensity to consume (MPC) out of profits and wages, and is expected to be negative. ${ }^{3}$

Private investment, I, is modelled as a positive function of output (the accelerator effect), and the profit share as a proxy for expected profitability as well as the availability of internal finance:

$$
I=i_{A}+i_{Y} Y+i_{\pi} \pi
$$

where $i_{A}$ is autonomous investment, and all parameters are expected to be positive. ${ }^{4}$

The marginal effect of $\pi$ on $\mathrm{I} / \mathrm{Y}$ is calculated as follows:

$$
\frac{\partial(I / Y)}{\partial(R / Y)}=i_{\pi} \frac{I}{R}
$$

The details of the derivation of the marginal effects are in Appendix C.

We model the effects of distribution on net exports via the stepwise approach of Stockhammer, et al. (2009) and Onaran, et al. (2011). Exports (X) are a function of export/import prices $\left(\mathrm{P}_{\mathrm{x}} / \mathrm{P}_{\mathrm{m}}\right)$ and the GDP of the rest of the world $\left(\mathrm{Y}_{\mathrm{rw}}\right)$; imports $(\mathrm{M})$ are a function of domestic prices/import prices $\left(\mathrm{P} / \mathrm{P}_{\mathrm{m}}\right)$ and GDP; domestic prices $(\mathrm{P})$ and export prices $\left(\mathrm{P}_{\mathrm{x}}\right)$ are functions of nominal unit labour cost (ulc) and import prices $\left(\mathrm{P}_{\mathrm{m}}\right)$. The exchange rate is included in export and import estimations wherever significant.

\footnotetext{
${ }^{3}$ In the developing countries, we also test whether the MPC differs between rural and urban regions by augmenting Equation (2) with agricultural GDP, $\mathrm{Y}_{\mathrm{a}}$. The coefficient of $\mathrm{Y}_{\mathrm{a}}$ is the difference between MPC in different regions.

${ }^{4}$ The long-term real interest rate is excluded since it was not statistically significant. In developing countries, we also add $\mathrm{Y}_{\mathrm{a}}$ in order to account for the differences in investment in agriculture, and government investments, $I_{\mathrm{g}}$, to test crowding-in or crowding-out effects.
} 
We calculate the marginal effect of a change in the wage share on exports/GDP as follows:

$$
\begin{aligned}
& \frac{\partial(X / Y)}{\partial(w s)}=\left(\frac{\partial X}{\partial P_{x}} \frac{\partial P_{x}}{\partial(u l c)} \frac{\partial(\text { ulc })}{\partial(\text { rulc })} \frac{\partial(\text { rulc })}{\partial(\text { ws })}\right) \frac{X / Y}{r u l c} \\
& =\left(e_{X P} e_{P_{x}} \frac{1}{1-e_{P}} \frac{Y f}{Y}\right) \frac{X / Y}{r u l c}
\end{aligned}
$$

where $e_{P_{x}}$ is the effect of ulc on $\mathrm{P}_{\mathrm{x}}$, and $e_{X P}$ is the effect of $\mathrm{P}_{\mathrm{x}}$ on exports. The wage share is real unit labour cost (rulc) multiplied by GDP at market prices/GDP at factor cost $\left(\mathrm{Y} / \mathrm{Y}_{\mathrm{f}}\right)$. The total effect of a change in the ws on exports includes the effect of rulc on $u l c^{5}$, the effect of ulc on prices, and the effect of $\mathrm{P}_{\mathrm{x}}$ on exports. The average values of $\frac{X / Y}{\text { rulc }}$ for the sample mean are used to convert the elasticity to marginal effect. A similar procedure is followed for imports

The sum of the partial effects of a change in $\pi$ on consumption, investment, and net exports on demand is the effect on private excess demand. The initial change in private excess demand will further affect consumption, investment, and imports via the multiplier mechanism.

The paper focuses on private demand, and does not investigate how government expenditures react to changes in income distribution, but as far as government expenditures and taxes influence GDP, it will affect investment, consumption and imports via multiplier effects. We also estimate the effects of government investment on private investment. A related research question would be how various taxes affect profit and wage income, and hence consumption. This is not possible with readily available data for all countries and would constitute a research question in its own right.

\subsection{The global interactions}

${ }^{5}$ The effect of real unit labor cost on nominal unit labor cost is $\frac{\partial(u l c)}{\partial(\text { rulc })}=\frac{1}{1-e_{p}}$, where $e_{p}$ is the effect of ulc on domestic prices. 
Next we incorporate the global effects of a change in $\pi$ simultaneously in all the economies. A change in $\pi$ of other countries affects the aggregate demand of each economy via the effects of changes in imports prices and the GDP of trade partners on its net exports.

For the case of n countries, the percentage change in the GDP of each country is

$$
\left[\begin{array}{c}
\frac{d Y_{1}}{Y_{1}} \\
\vdots \\
\frac{d Y_{n}}{Y_{n}}
\end{array}\right]=E_{n x n}\left[\begin{array}{c}
\delta \pi_{1} \\
\vdots \\
\delta \pi_{n}
\end{array}\right]+H_{n x n}\left[\begin{array}{c}
\frac{\delta Y_{1}}{Y_{1}} \\
\vdots \\
\frac{\delta Y_{n}}{Y_{n}}
\end{array}\right]+P_{n x n}\left[\begin{array}{c}
\delta \pi_{1} \\
\vdots \\
\delta \pi_{n}
\end{array}\right]+\left(W_{n x n}\right)\left[\begin{array}{c}
\frac{\delta Y_{1}}{Y_{1}} \\
\vdots \\
\frac{\delta Y_{n}}{Y_{n}}
\end{array}\right]
$$

where the matrices $\mathrm{E}$ and $\mathrm{H}$ represent only the effects of a change in each country's own $\pi$ on demand in that country. Matrices $\mathrm{P}$ and $\mathrm{W}$ add the effects of changes in imports prices and the GDP of trade partners on the net exports of each country on top of these national effects. E is a matrix, whose diagonal elements are the effect of a change in a country's own $\pi$ on private excess demand in that country. H reflects the national multiplier effects in country $i$ as an outcome of changes in private excess demand in that country. $\mathrm{P}$ shows the effect of a change in a trade partner's $\pi$, hence import prices on the net exports of each country. W shows the effects of a change in a trade partner's GDP on the exports of each country. The details are in Appendix D.

Solving Equation (6) for $\left[\frac{d Y}{Y}\right]$, we get the equivalent of a global cumulative/multiplier effect:

$$
\left[\begin{array}{c}
\frac{d Y_{1}}{Y_{1}} \\
\vdots \\
\frac{d Y_{n}}{Y_{n}}
\end{array}\right]=\left(I_{n x n}-H_{n x n}-W_{n x n}\right)^{-1}\left(E_{n x n}+P_{n x n}\right)\left[\begin{array}{c}
\delta \pi_{1} \\
\vdots \\
\delta \pi_{n}
\end{array}\right]
$$

So far both theoretical and empirical research has focused on the national effects, and ignored the spatial effects due to the simultaneous changes in distribution in the global economy. However, ignoring this spatial interaction overestimates the positive effects of a fall in the wage share. Higher openness of an economy increases the relevance of the positive effects of a fall in the wage share due to a higher share of net exports; however globalisation is not an isolated phenomenon, and there has 
been a global contagion of wage moderation policies as countries tried to compete based on wage costs. This, in turn, decreases the effects of a fall in the wage share on net exports when it is implemented simultaneously across countries as relative prices of exports and imports do not change much when all countries reduce their unit labour costs. Understanding the full effects of the fall in the wage share requires a global analysis of the economic geography of inequality and its consequences via spatial interactions.

\section{Estimation methodology}

We analyze the effects of the changes in the wage share on growth by means of estimating single equations for consumption, investment, exports, and imports for each country as is widely used in the literature (e.g., Onaran, et al, 2011; Stockhammer, et al, 2009; Hein and Vogel, 2008; Naastepad and Storm, 2007).

Unit root tests suggest that most of our variables are stationary only in their first differences. Only $\pi$ is stationary in the UK, Italy, Turkey, and Argentina. Error-correction models (ECM) are applied wherever significant. ${ }^{6}$ Otherwise specifications in difference form are estimated.

We start with a general specification with both the contemporaneous values and first lags of the variables as well as a lagged dependent variable. Then the specification with only significant values is chosen. Wherever there is autocorrelation, either the lagged dependent variable is kept, or an AR(1) term is added. Long-term elasticities are calculated for finding the marginal effects.

The single-equation approach has some advantages. It allows for a flexible modelling of the individual behavioural equations. However, there are three issues, which may cause a bias in the estimations. First, functional income distribution is assumed to be exogenous. Obviously this is not the case, e.g. lower growth and higher unemployment will have a negative effect on the wage share;

\footnotetext{
${ }^{6}$ We use the t-ratios reported by Banerjee et al. (1998) for the speed of adjustment coefficient to test the significance of cointegration.
} 
however this works usually with a time lag. By assuming exogeneity, we are implying that the time lag of this effect is longer than one year. Endogenizing income distribution is not feasible in the absence of good instrumental variables and long time series data, which could allow for using own lags of the distribution variables as instruments. Second, the single equation approach fails to utilize the fact that consumption, investment and net exports add up to private demand.

The main alternative, a VAR approach (as used by Stockhammer and Onaran (2004), Onaran and Stockhammer (2005), Barbosa-Filho and Taylor (2006)), would require substantially simplifying the model as these models cannot handle more than five endogenous variables. Such simplification is likely to lead to misspecification of the behavioural functions. Furthermore the results of VAR estimations are more difficult to interpret. It is not possible to detect and decompose the precise economic relationships that lead to changes in demand in response to distribution. Nevertheless, the convenience of interpretation of the results of the single equation approach comes at the price of some potential bias because the system-dimension and endogeneity are ignored.

Third, the global effects are calculated based on the separately estimated effects for each country. A Seemingly Unrelated Regression (SUR) approach was tested, however the correlation of the error terms across the country specific equations were not significant; thus we could not reject the hypothesis of independence.

\section{Estimation Results}

The estimations results for consumption are in Table 1. The hypothesis that the MPC out of profits and wages vary is confirmed in all countries. In cases where either of the lags of $\mathrm{W}$ or $\mathrm{R}$ is significant, we also kept the insignificant lag, since the sum of $\mathrm{W}$ and $\mathrm{R}$ gives the total income.

$<$ Table 1 $>$ 
The results for investment are summarized in Table $2 .^{7}$ In the US, Turkey, Korea, India, and China $\pi$ has no significant effect. ${ }^{8}$ In all countries, GDP has a strong significant effect on private investment. Furthermore, in Korea, India, and China public investment has a significant positive effect. The importance of industrial policy may explain the lack of statistically significant effect of profits in Korea and China.

$<$ Table 2>

The results for exports, imports and prices are in Tables 3-6. In Turkey, Mexico, and South Africa there are no significant effect of export prices on exports; so we estimate exports as a function of rulc. In South Africa there were no significant effects again. In the euro area and Germany there are no significant effect of either prices or rulc on imports.

$<$ Tables 3-6>

Table E.1 in Appendix E summarizes the marginal effect of a change in $\pi$ on $\mathrm{X} / \mathrm{Y}$ and $\mathrm{M} / \mathrm{Y}$. This effect not only depends on the elasticity of exports and imports to prices but also on the share of exports and imports in GDP. Thus in relatively small open economies the effect becomes much larger compared to the large closed economies.

${ }^{7}$ In the UK and Argentina, since $\pi$ is stationary, the ECM vector includes only I and Y; $\pi$ enters the specification as its level. In Italy and Turkey $\pi$ is used in its level form in the difference specifications, since it is stationary. $\mathrm{Y}_{\mathrm{a}}$ is significant only in South Africa.

${ }^{8}$ Seguino (1999), Onaran and Yentürk (2001), Onaran and Stockhammer (2005), Hein and Vogel (2008) similarly find no significant effects of $\pi$ on investment. Onaran, et al. (2011) show that when the interest and dividend payments are deducted from profits, there is a positive effect of the profit share on investment in the US. The effect of $\pi$ on private investment in China is also insignificant, although there is a positive effect on total investment including public investment. Molero Simarro (2011) and Wang (2009) also find a positive effect of profits on total investment. 


\subsection{National effects}

Table 7 summarizes the effects of a 1\%-point increase in $\pi$ on consumption, investment, exports, and imports.

$<$ Table 7>

The first column reports the partial effects on consumption, i.e. the differences in consumption propensities. The MPC out of profits is lower than that out of wages in all countries; thus a rise in $\pi$ leads to a decline in consumption. The second column reports the partial effects of $\pi$ on investment. If we sum up only the effects on domestic private demand (i.e., consumption and investment) the negative effect of the increase in $\pi$ on consumption is substantially larger than the positive effect on investment in absolute value in all countries. Thus demand in the domestic sector is clearly wage-led; however, the foreign sector then has a crucial role in determining whether the economy is profit-led.

Column F sums up the partial effects on private demand when $\pi$ increases in each country in isolation. Overall demand in the euro area as well as Germany, France, Italy, UK, US, and Japan is wage-led. The results indicate that large/relatively closed economies are rather wage-led than profitled. $^{9}$

\footnotetext{
${ }^{9}$ Our results are consistent with Stockhammer, et al. (2009), Stockhammer, et al. (2011), Hein and Vogel (2008), Ederer and Stockhammer (2007), and Onaran, et al. (2011). Bowles and Boyer (1995) find similar results for the US and UK, but profit-led regimes in Germany, France, and Japan, however there are unit root problems. Naastepad and Storm (2007) find profit-led regimes in the US and Japan, but these results are driven by the unconventional finding that the domestic demand is profit-led. They find similar results to us for Germany, France, Italy, the UK. Stockhammer and Onaran (2004) estimate a VAR model, and conclude that the impact of distribution on demand is
} 
Canada and Australia are profit-led; as small open economies the net export effects are high; the investment effects are also among the highest, and the consumption effects are among the lowest.

Among the developing countries, only Turkey and Korea are wage-led ${ }^{10}$. China is very strongly profit-led; however this effect is not due to investment, but rather results from the very strong net export effects due to a very high elasticity of prices to unit labour costs, indicating a highly labour intensive export structure as well as the highly price-elastic character of exports such as textiles. South Africa is also strongly profit-led due to a low difference in the MPC out of profits and wages. Mexico and Argentina also have profit-led regimes; in Mexico a strong effect of profits on both investment and net exports, and in Argentina a low MPC differential explain the results. India is profit-led but the effect of distribution is rather low; a high net export effect slightly offsets the low effect on consumption.

Column $\mathrm{G}$ reports the multiplier calculated using the elasticities of $\mathrm{C}$, I, and $\mathrm{M}$ with respect to Y. The details are in Appendix F. The multiplier is larger than one in all cases. When the multiplier effects are taken into consideration the effect of a change in distribution on demand becomes higher as can be seen in Column $\mathrm{H}$.

\subsection{Global effects}

Finally we analyze the global effects of a simultaneous 1\%-point increase in $\pi$ in all the economies. Column I in Table 8 summarizes the results.

Most interestingly, four profit-led countries, Canada, India, Mexico and Argentina, also start contracting after incorporating the effects of decreasing import prices and the GDP of trade partners. Thus, the expansionary effects of an increase in the profit share are reversed when relative weak. Again using VAR methodology Barbosa-Filho and Taylor (2006) find that the US is profitled; however there are serious autocorrelation issues.

${ }^{10}$ Onaran and Stockhammer (2005) also find that Turkey and Korea are wage-led. 
competitiveness effects are reduced as all countries are implementing a similar wage competition strategy. Comparing columns $\mathrm{H}$ and I, the wage-led economies experience stronger negative effects on demand now. The euro area, the UK, and Japan have 0.18-0.25\% lower demand than otherwise. In Turkey, Korea, and the US the negative effects on demand reaches to $0.72-0.92 \%$. Australia, South Africa, and China are the only countries that can continue to grow out of a simultaneous increase in $\pi$. However, the growth rates in these countries are also reduced in comparison.

Overall a 1\%-point simultaneous decline in the wage share in these economies leads to a decline in the global GDP growth by $0.36 \%$-points (the average of the growth rates in column I weighted by the share of each country in the world GDP). Hence, it is possible to find an alternative scenario, where all countries can grow along with an increase in the wage share, although the extent at which wage share can recover is more moderate in the profit-led countries compared to the wageled countries.

Finally, we checked the robustness of the results with respect to the adjusted wage share variable, since adjusting for the labour income of the self-employed is a challenge particularly for the developing countries. When the estimations are done using unadjusted wage share, the MPC differences are in general lower. This indicates that it is intuitively correct to adjust for the labour income of the self employed: MPC from unadjusted profit income is much higher compared to that out of adjusted profit income, since unadjusted profits incorporate self employed labour income with a relatively higher MPC. Nevertheless in most countries this does not lead to a change in the character of the regime. However in Korea, when unadjusted wages are used, the regime seems to be profit-led rather than wage-led primarily due to much lower MPC differences. In Mexico, the effect of the profit share on investment becomes insignificant, and therefore the regime seems to be wageled rather than profit-led. Overall, these differences do not affect the global results.

\section{Conclusions}


Our empirical estimations show that a simultaneous decline in the wage share in a highly integrated global economy leads to a decline in global growth, although the magnitude of the effect is not large. A cautious interpretation would suggest that an increase in the wage share and equality is not a barrier to growth if implemented simultaneously at the global level. Our results indicate that the contractionary effects of a fall in the wage share on consumption outweigh the expansionary effects on investment in all countries, a robust result consistent with previous research. Therefore, a simultaneous decline in the wage share in the world cannot possibly have expansionary effects on the global economy, since net export effects are fundamentally wiped out. Despite the potential biases that may result from endogeneity issues and single equation based estimations, our results are consistent with the intuition that the world as a whole is a closed economy. Hence, one result stands out: planet earth in aggregate is wage-led.

The results indicate that the micro rationale of pro-capital redistribution conflicts with the macro outcomes: First, in a wage-led economy the consequence of a higher profit share at the macroeconomic level is lower demand; thus even though a higher profit share at the firm level seems to be beneficial to individual employers, at the macroeconomic level a generalized fall in the wage share generates a problem of realization of profits due to deficient demand. Second, in the profit-led countries even if increasing profit share seems to be promoting growth at the national level, at the global level a generalized fall in the wage share leads to a global demand deficiency. What seems to be rational at the level of an individual firm or a country turns out to be contractionary at the macro or global level.

These results have important policy conclusions. First, if a country is wage-led, increasing equality is not an impediment to growth. Second, for the large economic areas with low extraregional trade, like the euro area, which tend to be wage-led, macroeconomic policy coordination, in particular wage policy coordination, can improve growth and employment. There is also room for egalitarian and regional demand oriented growth via south-south cooperation in the developing 
world. Third, a wage-led recovery as a way out of the global recession is feasible; an increase in the wage share could stimulate global growth, if the coordination problem among the countries can be overcome. Given the profit-led structures in some developing countries, the solution to the coordination problem requires the initiative of some large wage-led developed economies towards egalitarian growth. This in turn can create space for domestic demand-led growth strategies in the developing countries. 


\section{References}

Aghion, P., Caroli, E. and C. García-Peñalosa (1999), “Inequality and Economic Growth: The Perspective of the New Growth Theories”, Journal of Economic Literature, 37:1615-1660.

Alesina, A. and D. Rodrik (1994), “Distributive Politics and Economic Growth”, The Quarterly Journal of Economics, 109(2):465-490.

Alesina A. and Perotti R. (1996) "Income Distribution, Political Instability and Investment", European Economic Review, 40: 1203-1228.

Atkinson, A. (2009), “Factor Shares: The Principal Problem of Political Economy?”, Oxford Review of Economic Policy 25(1):3-16.

Barro, R. (2000), “Inequality and Growth in a Panel of Countries”, Journal of Economic Growth, 5: 5-32.

Banerjee, A, Dolado, J, Mestre, R,, (1998), “Error correction mechanism test for cointegration in a single equation framework” Journal of Time Series Analysis 19(3):267-283

Barbosa-Filho, N. and Taylor, L. (2006). "Distributive and demand cycles in the US economy - a structuralist Goodwin model”, Metroeconomica 57(3):389-411

Bhaduri, A., and S. Marglin, (1990). "Unemployment and the real wage: the economic basis for contesting political ideologies,” Cambridge Journal of Economics, 14:375-93

Blecker, R. (1989), “International competition, income distribution and economic growth” Cambridge Journal of Economics, 13:395-412

Bowles, S, and Boyer, R, (1995), "Wages, aggregate demand, and employment in an open economy: an empirical investigation” (pp.143-171), in G Epstein and H Gintis (eds): Macroeconomic Policy after the Conservative Era. Studies in Investment, Saving and Finance (Cambridge: Cambridge University Press)

Dafermos, Y. and C. Papatheodorou (2011), “Functional and Personal Income Distribution in a Stock-Flow Consistent Model”, 15th Conference of the Research Network Macroeconomics and Macroeconomic Policies, Berlin, 28-29 October

Daudey, E. and C, Garcia-Penalosa (2007), “The Personal and the Factor Distributions of Income in a Cross-Section of Countries”, Journal of Development Studies, 43(5):812-829.

Dutt, A. (1984), “Stagnation, Income Distribution and Monopoly Power”, Cambridge Journal of Economics, 8:25-40

Ederer, S. and Stockhammer, E. (2007). "Wages and aggregate demand in France: An empirical investigation” (119-138), in Hein, E, Truger, A (eds), Money, Distribution, and Economic Policy - Alternatives to Orthodox Macroeconomics. (Cheltenham: Edward Elgar) 
European Commission (2006). Time to move up a gear: the new partnership for jobs and growth, http://ec.europa.eu/growthandjobs/pdf/illustrated-version_en.pdf

European Commission (2007), “The labour income share in the European Union”, Employment in Europe, Brussels.

Galor, O. and J. Zeira (1993), "Income Distribution and Macroeconomics”, Review of Economic Studies, 60:35-52.

Gollin, D. (2002). “Getting Income Shares Right”. Journal of Political Economy, 110(2):458-74. Hein, E. and Vogel, L. (2008). "Distribution and growth reconsidered -empirical results for six OECD countries”, Cambridge Journal of Economics, 32, 479-511

ILO/IILS (2011). World of Work Report, ILO/International Institute for Labour Studies, Geneva IMF (2007). "Spillovers and Cycles in the Global Economy, World Economic and Financial Surveys“, in World Economic Outlook, IMF, Washington,D.C.

Jäntti, M., (1997), “Inequality in Five countries in the 1980s: The Role of Demographic Shifts, Markets and Government Policies”, Economica, 64:415-440.

Jetin, B. and Kurt, O. (2011). "Functional Income Distribution and Growth in Thailand: Single Equation Estimations Based on Bhaduri/Marglin Model”, Annual Conference of the Research Network Macroeconomics and Macroeconomic Policies, October 28-29, Berlin Kaldor, N. (1956), “Alternative Theories of Distribution”, Review of Economic Studies, 23(2):83100.

Lindenboim,J., Kennedy, D. And Graña, J.M., (2011). “Wage share and aggregate demand: Contributions for labour and macroeconomic policy”, Regulating for Decent Work Conference, Geneva, July 6-8.

Mirrlees, J.A. (1971) “An Exploration in the Theory of Optimum Income Taxation,” Review of Economic Stuies, 38(114):175-208.

Molero Simarro, R. (2011), "Functional Distribution of Income and Economic Growth in the Chinese Economy, 1978-2007”, SOAS Department of Economics Working Papers, No.168 Naastepad, C.W.M., and S. Storm (2006/7). “OECD demand regimes (1960-2000)” Journal of PostKeynesian Economics, 29:213-248.

Onaran, Ö. and Yentürk, N., (2001). "Do Low Wages Stimulate Investments? An Analysis of the Relationship between Distribution and Investments in Turkish Manufacturing Industry”, International Review of Applied Economics, 15(4):359-374.

Onaran, Ö, and E. Stockhammer (2005). “Two different export-oriented growth strategies: accumulation and distribution a la Turca and a la South Korea” Emerging Markets Finance and Trade 41(1):65-89 
Onaran, Ö, E Stockhammer, and L. Grafl (2011). “The finance-dominated growth regime, distribution, and aggregate demand in the US” Cambridge Journal of Economics 35(4):637661

Persson, T. and G. Tabellini (1994), “Is Inequality Harmful for Growth?”, The American Economic Review, 84(3):600-621.

Rodrik, D. (1997), Has globalisation gone too far?, Institute for International Economics, Washington DC.

Seguino, S., (1999). “The Investment Function Revisited: Disciplining Capital in South Korea”, Journal of Post-Keynesian Economics, 22(2):313-38

Stockhammer, E. (2013). Why have wage shares fallen?, Conditions of Work and Employment Series No.35, ILO, Geneva

Stockhammer, E., and Ö. Onaran (2004), “Accumulation, distribution and employment: a structural VAR approach to a Kaleckian macro-model” Structural Change and Economic Dynamics, 15:421-47.

Stockhammer, E., Onaran, Ö., and Ederer, S. (2009), “Functional income distribution and aggregate demand in the Euro area” Cambridge Journal of Economics, 33(1):139-159

Stockhammer, E., E. Hein and L. Grafl (2011) “Globalization and the effects of changes in functional income distribution on aggregate demand in Germany”, International Review of Applied Economics, 25(1):1-23.

Wang, P. (2009). Three Essays on Monetary Policy and Economic Growth in China, Unpublished $\mathrm{PhD}$. Thesis, University of Ottawa.

Wolff, E, and A. Zacharias (2007) Class structure and economic inequality. Levy Economics Institute Working Paper No.487

Zhou, M., Xiao, W., and Yao, X. (2010). “Unbalanced Economic Growth and Uneven National Income Distribution: Evidence from China”, Institute for Research on Labor and Employment Working Paper 2010-11. University of California 

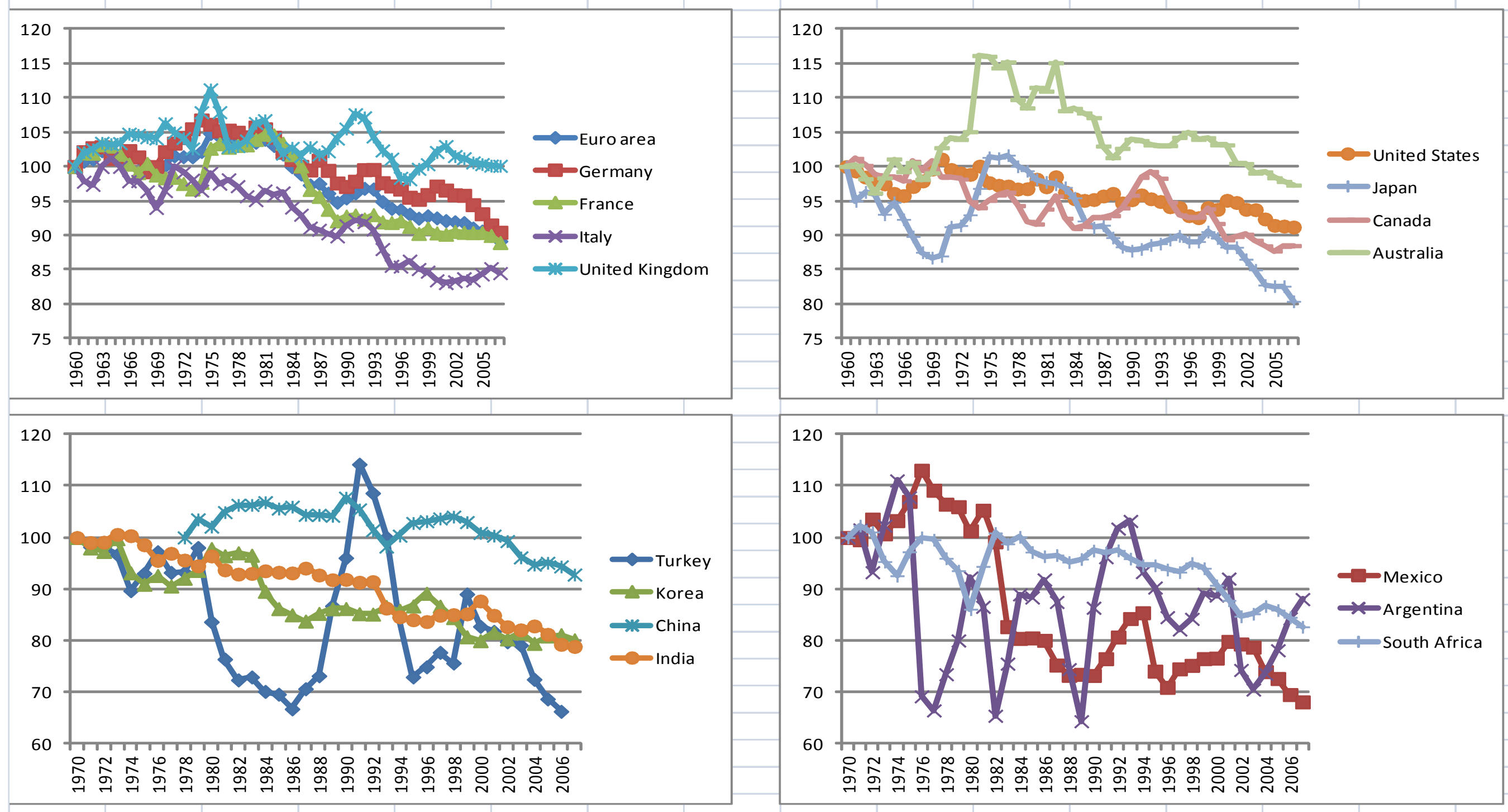

Source: See Appendix A 
Table 1: Consumption: dependent variable $\operatorname{dlog}(\mathrm{C})$

\begin{tabular}{|c|c|c|c|c|c|c|c|c|c|c|c|c|c|c|c|c|c|c|c|c|c|c|c|}
\hline & c & t-value & & $d \log (R t)$ & t-value & & $\mathrm{dlog}(\mathrm{Wt})$ & t-value & & DW & R2 & \multicolumn{2}{|c|}{ Sample } & & & & & & & & & & \\
\hline Euro area-12 & 0.006 & 3.110 & $* * *$ & 0.127 & 3.716 & $* * *$ & 0.739 & 15.406 & $* * *$ & 1.871 & 0.873 & \multicolumn{2}{|c|}{19612007} & & & & & & & & & & \\
\hline Germany & 0.007 & 2.439 & $* *$ & 0.091 & 1.576 & & 0.714 & 10.162 & $* * *$ & 1.954 & 0.713 & \multicolumn{2}{|c|}{19612007} & & & & & & & & & & \\
\hline France & 0.007 & 3.153 & $* * *$ & 0.137 & 4.717 & $* * *$ & 0.640 & 10.770 & $* * *$ & 2.120 & 0.771 & \multicolumn{2}{|c|}{19612007} & & & & & & & & & & \\
\hline Italy & 0.008 & 2.474 & $* *$ & 0.167 & 4.101 & $* * *$ & 0.711 & 8.621 & $* * *$ & 1.515 & 0.705 & \multicolumn{2}{|c|}{19612007} & & & & & & & & & & \\
\hline Australia & 0.017 & 4.394 & $* * *$ & 0.098 & 3.295 & $* * *$ & 0.440 & 5.463 & $* * *$ & 1.831 & 0.411 & \multicolumn{2}{|c|}{19612007} & & & & & & & & & & \\
\hline & c & t-value & & dlog(Rt) & t-value & & $\mathrm{d} \log (\mathrm{Wt})$ & $t$-value & & $\operatorname{ar}(1)$ & $t$-value & & DW & R2 & Sample & & & & & & & & \\
\hline UK & 0.006 & 1.501 & & 0.162 & 5.200 & $* * *$ & 0.735 & 6.852 & $* * *$ & 0.331 & 2.173 & $* *$ & 1.838 & 0.683 & 19622007 & & & & & & & & \\
\hline Canada & 0.007 & 1.911 & $*$ & 0.160 & 6.268 & $* * *$ & 0.659 & 6.852 & $* * *$ & 0.411 & 2.904 & $* * *$ & 1.935 & 0.725 & 19622007 & & & & & & & & \\
\hline & C & $t$-value & & dlog(Rt) & $t$-value & & $\mathrm{d} \log (\mathrm{Wt})$ & t-value & & $\mathrm{d} \log (\mathrm{Rt}-1)$ & $t$-value & & dlog(Wt-1) & $t$-value & dlog(Ct-1) & $t$-value & & DW & $\mathrm{R} 2$ & Sam & aple & & \\
\hline US & 0.012 & 4.048 & $* * *$ & 0.181 & 4.968 & $* * *$ & 0.536 & 6.509 & $* * *$ & -0.114 & -2.523 & $* *$ & -0.140 & -1.389 & 0.247 & 1.517 & & 2.017 & 0.822 & 196 & 22007 & & \\
\hline & c & t-value & & dlog(Rt-1) & $t$-value & & dlog(Wt-1) & $t$-value & & DW & R2 & \multicolumn{2}{|c|}{ Sample } & & & & & & & & & & \\
\hline Japan & 0.011 & 2.256 & $* *$ & 0.083 & 2.103 & $* *$ & 0.611 & 6.747 & $* * *$ & 2.300 & 0.599 & \multicolumn{2}{|c|}{19622007} & & & & & & & & & & \\
\hline & c & $t$-value & & $d \log (R t)$ & $t$-value & & $d \log (W t)$ & t-value & & $\mathrm{d} \log (\mathrm{Rt}-1)$ & $t$-value & & dlog(Wt-1) & $t$-value & $\mathrm{d} \log (\mathrm{Ct}-1)$ & $t$-value & DW & R2 S & Sample & & & & \\
\hline Turkey & 0.008 & 0.506 & & 0.328 & 2.840 & $* * *$ & 0.316 & 2.432 & $* *$ & 0.088 & 0.688 & & 0.275 & 1.824 & -0.151 & -0.873 & 1.803 & 0.3201 & 197220 & & & & \\
\hline & c & t-value & & $d \log (R t)$ & t-value & & $d \log (W t)$ & t-value & & DW & $\mathrm{R} 2$ & \multicolumn{2}{|c|}{ Sample } & & & & & & & & & & \\
\hline Korea & -0.004 & -0.411 & & 0.072 & 3.820 & $* * *$ & 0.845 & 7.603 & $* * *$ & 2.073 & 0.641 & \multicolumn{2}{|c|}{19712007} & & & & & & & & & & \\
\hline Argentina & 0.003 & 0.575 & & 0.430 & 7.927 & $* * *$ & 0.579 & 13.903 & $* * *$ & 1.944 & 0.855 & \multicolumn{2}{|c|}{19712007} & & & & & & & & & & \\
\hline & c & $t$-value & & dlog(Rt) & $t$-value & & $d \log (W t)$ & t-value & & $A R(1)$ & t-value & & DW & $\mathrm{R} 2$ & Sample & & & & & & & & \\
\hline Mexico & 0.006 & 1.263 & & 0.376 & 7.625 & $* * *$ & 0.566 & 17.015 & $* * *$ & 0.477 & 3.021 & $* * *$ & 1.878 & 0.905 & 19722007 & & & & & & & & \\
\hline & c & t-value & & $d \log (R t)$ & t-value & & $d \log (W t)$ & t-value & & dlog(Rt-1) & t-value & & dlog(Wt-1) & t-value & DW & $\mathrm{R} 2$ & \multicolumn{2}{|c|}{ Sample } & & & & & \\
\hline China & -0.011 & -0.583 & & 0.427 & 3.731 & $* * *$ & 0.428 & 1.923 & $*$ & -0.186 & -1.571 & & 0.326 & 1.643 & 2.041 & 0.593 & \multicolumn{2}{|c|}{19802007} & & & & & \\
\hline & c & t-value & & $d \log (R t)$ & t-value & & $\mathrm{d} \log (\mathrm{Wt})$ & t-value & & $d \log (\mathrm{Rt}-1)$ & t-value & & $d \log (W t-1)$ & $t$-value & dlog(Yat) & $t$-value & \multicolumn{4}{|c|}{ dlog(Yat- $t$-value } & DW & R2 & Sample \\
\hline India & 0.003 & 0.530 & & 0.123 & 3.270 & $* * *$ & 0.586 & 4.317 & $* * *$ & 0.028 & 0.903 & & 0.158 & 1.319 & -0.009 & -0.100 & & -0.168 & -2.324 & $* *$ & 1.894 & 0.809 & 19722007 \\
\hline & c & t-value & & $d \log (R t)$ & $t$-value & & $d \log (W t)$ & t-value & & dlog(Yat) & $t$-value & & DW & R2 & Sample & & & & & & & & \\
\hline South Africa & 0.009 & 2.939 & $* * *$ & 0.312 & 9.030 & $* * *$ & 0.785 & 10.101 & $* * *$ & -0.061 & -3.400 & $* * *$ & 1.926 & 0.781 & 19712007 & & & & & & & & \\
\hline
\end{tabular}

Note: *,**, and $* * *$ stand for $10 \%, 5 \%$, and $1 \%$ significance levels respectively 
Table 2: Private Investment: dependent variable dlog(I)

\begin{tabular}{|c|c|c|c|c|c|c|c|c|c|c|c|c|c|c|c|c|c|c|c|c|c|c|c|c|}
\hline & c & $t$-value & & $\operatorname{dlog}(Y t)$ & $t$-value & & $\operatorname{dlog}(\pi \mathrm{t})$ & t-value & & dlog (It-1) & t-value & & $\log (I t-1)$ & t-value & & $\log \left(Y_{t-1}\right)$ & $t$-value & & $\log (\pi t-1)$ & t-value & & DW & R2 & Sample \\
\hline Euro area-12 & -0.304 & -1.916 & $*$ & 2.238 & 9.801 & $* *$ & -0.137 & -0.920 & & 0.088 & 1.105 & & -0.203 & -4.272 & $* *$ & 0.207 & 4.545 & $* *$ & 0.093 & 2.356 & ** & 1.820 & 0.865 & 19622007 \\
\hline Germany & -0.136 & -0.628 & & 1.805 & 6.398 & $* *$ & 0.058 & 0.284 & & 0.183 & 1.683 & $*$ & -0.292 & -3.756 & $* *$ & 0.266 & 4.283 & $* *$ & 0.172 & 2.050 & $* *$ & 1.829 & 0.748 & 19622007 \\
\hline & C & $t$-value & & $\mathrm{dlog}(\pi \mathrm{t}-1)$ & $t$-value & & $\mathrm{dlog}(\mathrm{Yt})$ & t-value & & $\operatorname{ar}(1)$ & t-value & & DW & $R 2$ & \multicolumn{2}{|c|}{ Sample } & & & & & & & & \\
\hline France & -0.027 & -2.654 & $* *$ & 0.139 & 1.657 & $*$ & 2.050 & 10.505 & $* * *$ & 0.670 & 5.569 & $* * *$ & 1.832 & 0.822 & \multicolumn{2}{|c|}{19632007} & & & & & & & & \\
\hline & c & $t$-value & & $\log (\pi \mathrm{t}-1)$ & $t$-value & & $\mathrm{dlog}(\mathrm{Yt})$ & $t$-value & & $\operatorname{dlog}(Y t-1)$ & $t$-value & & DW & $R 2$ & \multicolumn{2}{|c|}{ Sample } & & & & & & & & \\
\hline Italy & 0.229 & 5.449 & $* * *$ & 0.241 & 6.084 & $* * *$ & 2.094 & 8.819 & $* * *$ & 0.516 & 2.421 & $* *$ & 2.524 & 0.622 & \multicolumn{2}{|c|}{19622007} & & & & & & & & \\
\hline & c & $t$-value & & $\log (\pi t-1)$ & $t$-value & & $\mathrm{dlog}(\mathrm{Yt})$ & t-value & & $\log ($ It-1) & $t$-value & & $\log \left(Y_{t-1}\right)$ & $t$-value & & DW & $R 2$ & \multicolumn{2}{|c|}{ Sample } & & & & & \\
\hline UK & -1.143 & -2.500 & $* *$ & 0.212 & 2.513 & $* *$ & 1.660 & 5.429 & $* * *$ & -0.350 & -3.392 & $* * *$ & 0.458 & 3.278 & $* * *$ & 1.870 & 0.593 & \multicolumn{2}{|c|}{19612007} & & & & & \\
\hline & c & $t$-value & & $\operatorname{dlog}(\pi t-1)$ & $t$-value & & $d \log (Y t)$ & t-value & & dlog(Yt-1) & t-value & & $\operatorname{ar}(1)$ & $t$-value & & DW & $R 2$ & \multicolumn{2}{|c|}{ Sample } & & & & & \\
\hline US & -0.061 & -4.519 & $* * *$ & 0.077 & 0.510 & & 2.738 & 14.501 & $* * *$ & 0.367 & 1.824 & $*$ & 0.612 & 4.817 & $* * *$ & 1.697 & 0.858 & \multicolumn{2}{|c|}{19632007} & & & & & \\
\hline & c & $t$-value & & $\mathrm{dlog}(\pi \mathrm{t})$ & $t$-value & & $\operatorname{dlog}(I t-1)$ & $t$-value & & $\operatorname{dlog}(Y t)$ & $t$-value & & $\operatorname{dlog}(\mathrm{Yt}-1)$ & $t$-value & & DW & $R 2$ & \multicolumn{2}{|c|}{ Sample } & & & & & \\
\hline Japan & -0.019 & -2.845 & $* * *$ & 0.185 & 2.615 & $* *$ & 0.485 & 3.806 & $* * *$ & 1.982 & 12.339 & $* * *$ & -1.034 & -3.221 & $* * *$ & 2.126 & 0.924 & \multicolumn{2}{|c|}{19622007} & & & & & \\
\hline & C & $t$-value & & $\operatorname{dlog}(\pi t-1)$ & $t$-value & & $\operatorname{dlog}(Y t)$ & t-value & & DW & $R 2$ & \multicolumn{2}{|c|}{ Sample } & & & & & & & & & & & \\
\hline Canada & -0.020 & -1.711 & $*$ & 0.318 & 1.874 & * & 1.780 & 6.018 & $* * *$ & 1.593 & 0.530 & \multicolumn{2}{|c|}{19622007} & & & & & & & & & & & \\
\hline & c & $t$-value & & $\mathrm{dlog}(\pi \mathrm{t})$ & $t$-value & & $\mathrm{dlog}(\mathrm{Yt})$ & t-value & & DW & $R 2$ & \multicolumn{2}{|c|}{ Sample } & & & & & & & & & & & \\
\hline Australia & -0.025 & -1.550 & & 0.256 & 1.857 & $*$ & 2.021 & 5.031 & $* * *$ & 1.821 & 0.494 & \multicolumn{2}{|c|}{19612007} & & & & & & & & & & & \\
\hline & c & $t$-value & & $\log (\pi \mathrm{t})$ & $t$-value & & $\mathrm{dlog}(\mathrm{Yt})$ & $t$-value & & DW & $R 2$ & \multicolumn{2}{|c|}{ Sample } & & & & & & & & & & & \\
\hline Turkey & -0.056 & -0.547 & & 0.041 & 0.294 & & 3.343 & 6.456 & $* * *$ & 1.743 & 0.567 & \multicolumn{2}{|c|}{19712006} & & & & & & & & & & & \\
\hline & c & $t$-value & & $\log (\pi t)$ & t-value & & $\log (\pi \mathrm{t}-1)$ & t-value & & $\operatorname{dlog}(Y t)$ & $t$-value & & $\mathrm{dlog}(\mathrm{Yt}-1)$ & t-value & \multicolumn{2}{|r|}{$\log (I t-1)$} & $t$-value & & $\log \left(Y_{t-1}\right)$ & t-value & & DW & R2 & Sample \\
\hline \multirow[t]{2}{*}{ Argentina } & 0.135 & 0.111 & & 0.190 & 2.596 & $* *$ & -0.147 & -2.165 & $* *$ & 2.808 & 19.169 & & 0.325 & 2.001 & $* *$ & -0.164 & -3.138 & $* * *$ & 0.147 & 1.895 & $*$ & 1.982 & 0.943 & 19722007 \\
\hline & c & $t$-value & & $\operatorname{dlog}(Y t)$ & $t$-value & & $\mathrm{d} \log (\pi \mathrm{t})$ & t-value & & $\mathrm{dlog}(\pi \mathrm{t}-1)$ & t-value & & dlog (It-1) & t-value & \multicolumn{2}{|c|}{$\log (I t-1)$} & $t$-value & & $\log (Y t-1)$ & $t$-value & \multicolumn{2}{|c|}{$\log (\pi t-1)$} & \multicolumn{2}{|c|}{$t$-value } \\
\hline Mexico & -1.778 & -2.722 & $* *$ & 3.336 & 13.407 & $* * *$ & -0.349 & -2.044 & $* *$ & -0.259 & -1.511 & & -0.040 & -0.616 & & -0.343 & -4.383 & $* * *$ & 0.482 & 3.765 & $* * *$ & 0.170 & 1.973 & $*$ \\
\hline & c & $t$-value & & $\operatorname{dlog}(\pi \mathrm{t}-1)$ & $t$-value & & $\mathrm{dlog}(\mathrm{Yt})$ & t-value & & dlog (lgt) & t-value & DW & $R 2$ & Sample & & & & & & & & & & \\
\hline Korea & -0.110 & -5.834 & $* * *$ & -0.011 & -0.311 & & 2.509 & 10.320 & $* * *$ & 0.186 & 1.960 & 1.589 & 0.816 & 19722007 & & & & & & & & & & \\
\hline & c & $t$-value & & $\mathrm{d} \log (\pi \mathrm{t})$ & t-value & & dlog (It-1) & t-value & & $\operatorname{dlog}(Y)$ & $t$-value & & dlog (lgt-1) & $t$-value & & DW & $R 2$ & Sam & nple & & & & & \\
\hline China & -0.061 & -0.549 & & -1.642 & -1.153 & & -0.184 & -0.786 & & 2.405 & 1.741 & & 0.492 & 1.726 & $*$ & 1.805 & 0.259 & 1980 & 02007 & & & & & \\
\hline & c & $t$-value & & $\mathrm{dlog}(\pi \mathrm{t})$ & t-value & & $\mathrm{dlog}(\mathrm{Yt})$ & $t$-value & & dlog (Igt-1) & $t$-value & DW & $R 2$ & Sample & & & & & & & & & & \\
\hline India & -0.018 & -0.682 & & -0.164 & -1.190 & & 1.561 & 3.856 & $* * *$ & \begin{tabular}{|l|} 
\\
0.402 \\
\end{tabular} & 2.868 & 2.369 & 0.421 & 19722007 & & & & & & & & & & \\
\hline & $c$ & $t$-value & & $\operatorname{dlog}(\pi t-1)$ & $t$-value & & $\operatorname{dlog}(Y t-1)$ & t-value & & dlog (Yat-1) & $t$-value & DW & $R 2$ & Sample & & & & & & & & & & \\
\hline South Africa & -0.010 & -0.573 & & 0.326 & 1.833 & $*$ & 1.912 & 3.408 & $* * *$ & -0.179 & -1.782 & 1.696 & 0.351 & 19722007 & & & & & & & & & & \\
\hline
\end{tabular}

Note: $*$, $* *$, and $* * *$ stand for $10 \%, 5 \%$, and $1 \%$ significance levels respectively 
Table 3: Price deflator: dependent variable $\operatorname{dlog}(\mathrm{P})$

\begin{tabular}{|c|c|c|c|c|c|c|c|c|c|c|c|c|c|c|c|c|c|c|}
\hline & $\mathrm{C}$ & t-value & & dlog(ULCt-1) & t-value & & dlog(Pmt) & t-value & & DW & $\mathrm{R} 2$ & \multicolumn{2}{|c|}{ Sample } & & & & & \\
\hline Euro area-12 & 0.014 & 3.518 & $* * *$ & 0.624 & 7.846 & $* * *$ & 0.123 & 2.915 & $* * *$ & 1.515 & 0.747 & \multicolumn{2}{|c|}{19622007} & & & & & \\
\hline Italy & 0.018 & 3.525 & $* * *$ & 0.604 & 9.320 & $* * *$ & 0.202 & 4.988 & $* * *$ & 1.731 & 0.827 & \multicolumn{2}{|c|}{19622007} & & & & & \\
\hline UK & 0.018 & 3.018 & $* * *$ & 0.568 & 6.713 & $* * *$ & 0.190 & 2.993 & $* * *$ & 2.039 & 0.691 & \multicolumn{2}{|c|}{19622007} & & & & & \\
\hline Japan & 0.013 & 3.227 & $* * *$ & 0.516 & 6.833 & $* * *$ & 0.095 & 3.100 & $* * *$ & 1.666 & 0.630 & \multicolumn{2}{|c|}{19622007} & & & & & \\
\hline Canada & 0.016 & 3.983 & $* * *$ & 0.459 & 5.335 & $* * *$ & 0.257 & 4.481 & $* * *$ & 1.447 & 0.678 & \multicolumn{2}{|c|}{19622007} & & & & & \\
\hline & C & t-value & & dlog(ULCt) & t-value & & dlog(Pmt) & t-value & & DW & $\mathrm{R} 2$ & \multicolumn{2}{|c|}{ Sample } & & & & & \\
\hline Germany & 0.012 & 8.103 & $* * *$ & 0.618 & 16.023 & $* * *$ & 0.031 & 1.428 & & 1.491 & 0.864 & \multicolumn{2}{|c|}{19612007} & & & & & \\
\hline & C & $t$-value & & dlog(ULCt-1) & $t$-value & & dlog(Pt-1) & t-value & & dlog(Pmt) & t-value & & DW & $\mathrm{R} 2$ & \multicolumn{2}{|c|}{ Sample } & & \\
\hline France & 0.007 & 2.360 & $* *$ & 0.275 & 2.141 & $* *$ & 0.522 & 3.394 & $* * *$ & 0.086 & 3.281 & $* * *$ & 1.809 & 0.907 & \multicolumn{2}{|c|}{19622007} & & \\
\hline & C & t-value & & dlog(ULCt-1) & t-value & & dlog(Pt-1) & t-value & & dlog(Pmt) & t-value & & dlog(Pmt-1) & t-value & & DW & $\mathrm{R} 2$ & Sample \\
\hline US & 0.009 & 5.219 & $* * *$ & 0.211 & 2.710 & $* *$ & 0.429 & 4.836 & $* * *$ & 0.109 & 8.403 & $* * *$ & 0.044 & 2.590 & $* *$ & 1.745 & 0.951 & 19622007 \\
\hline & C & $t$-value & & dlog(ULCt) & t-value & & dlog(Pmt) & t-value & & dlog(Pmt-1) & t-value & & DW & R2 & \multicolumn{2}{|c|}{ Sample } & & \\
\hline Australia & 0.016 & 4.324 & $* * *$ & 0.624 & 8.856 & $* * *$ & -0.031 & -0.579 & & 0.150 & 3.429 & $* * *$ & 1.976 & 0.814 & \multicolumn{2}{|c|}{19622007} & & \\
\hline & C & $t$-value & & dlog(ULCt) & $t$-value & & dlog(Pt-1) & t-value & & dlog(Pmt) & t-value & & DW & R2 & \multicolumn{2}{|c|}{ Sample } & & \\
\hline Turkey & 0.011 & 0.643 & & 0.354 & 5.402 & $* * *$ & 0.263 & 4.280 & $* * *$ & 0.364 & 7.124 & $* * *$ & 2.196 & 0.949 & \multicolumn{2}{|c|}{19722006} & & \\
\hline & C & $t$-value & & $\operatorname{dlog}(U L C t)$ & $t$-value & \multicolumn{3}{|c|}{ dlog(ULCt-1 t-value } & & $\operatorname{dlog}(P t-1)$ & t-value & & dlog(Pmt) & $t$-value & & DW & $\mathrm{R} 2$ & Sample \\
\hline \multirow[t]{2}{*}{ Mexico } & 0.008 & 0.884 & & 0.700 & 8.642 & $* * *$ & -0.265 & -2.136 & $* *$ & 0.309 & 2.875 & $* * *$ & 0.261 & 7.178 & $* * *$ & 2.387 & 0.979 & 19722007 \\
\hline & C & $t$-value & & dlog(ULCt) & & & dlog(Pmt) & $t$-value & & dlog(Pmt-1) & $t$-value & & DW & $\mathrm{R} 2$ & \multicolumn{2}{|c|}{ Sample } & & \\
\hline \multirow[t]{2}{*}{ Korea } & 0.016 & 3.026 & $* * *$ & 0.735 & 10.508 & $* * *$ & 0.073 & 1.709 & $*$ & 0.095 & 2.685 & $* *$ & 1.887 & 0.912 & 1972 & 2007 & & \\
\hline & C & t-value & & dlog(ULCt) & t-value & & dlog(Pmt) & t-value & & DW & R2 & \multicolumn{2}{|c|}{ Sample } & & & & & \\
\hline Argentina & 0.002 & 0.162 & & 0.640 & 17.025 & $* * *$ & 0.359 & 9.597 & $* * *$ & 1.828 & 0.994 & \multicolumn{2}{|c|}{19712007} & & & & & \\
\hline India & 0.023 & 5.114 & $* * *$ & 0.756 & 12.205 & $* * *$ & 0.009 & 0.401 & & 2.020 & 0.854 & \multicolumn{2}{|c|}{19712007} & & & & & \\
\hline \multirow[t]{2}{*}{ South Africa } & 0.033 & 2.611 & $* *$ & 0.618 & 5.634 & $* * *$ & 0.124 & 1.946 & $*$ & 1.897 & 0.567 & \multicolumn{2}{|c|}{19712007} & & & & & \\
\hline & C & t-value & & dlog(ULCt) & t-value & & dlog(Pt-1) & t-value & & dlog(Pmt) & t-value & DW & $\mathrm{R} 2$ & Sample & & & & \\
\hline China & 0.009 & 1.643 & $*$ & 0.771 & 7.480 & $* * *$ & 0.066 & 0.602 & & 0.030 & 0.831 & 1.425 & 0.864 & 1979200 & & & & \\
\hline
\end{tabular}

Note: *, **, and ${ }^{* * *}$ stand for $10 \%, 5 \%$, and $1 \%$ significance levels respectively 
Table 4: Export price deflator: dependent variable dlog(Px)

\begin{tabular}{|c|c|c|c|c|c|c|c|c|c|c|c|c|c|c|c|c|c|c|c|c|c|c|c|c|}
\hline & $c$ & t-value & & dlog(ULCt-1) & $t$-value & & dlog(Pxt-1) & t-value & & $\mathrm{dlog}(\mathrm{Pmt})$ & $t$-value & & DW & R2 & \multicolumn{2}{|c|}{ Sample } & & & & & & & & \\
\hline Euro area-12 & 0.003 & 1.670 & $*$ & 0.165 & 3.141 & $* * *$ & 0.102 & 2.504 & $* *$ & 0.566 & 27.168 & $* * *$ & 1.586 & 0.970 & \multicolumn{2}{|c|}{19622007} & & & & & & & & \\
\hline Germany & 0.004 & 1.557 & & 0.216 & 2.845 & $* * *$ & 0.214 & 2.631 & $* *$ & 0.355 & 9.780 & $* * *$ & 1.719 & 0.813 & \multicolumn{2}{|c|}{19622007} & & & & & & & & \\
\hline \multirow[t]{2}{*}{ Italy } & 0.004 & 0.960 & & 0.178 & 2.616 & $* *$ & 0.156 & 2.695 & $* *$ & 0.569 & 19.040 & $* * *$ & 2.495 & 0.946 & \multicolumn{2}{|c|}{19622007} & & & & & & & & \\
\hline & $c$ & $t$-value & & $\log ($ Pxt-1) & $t$-value & & $\log (\mathrm{ULCt}-1)$ & $t$-value & & $\log ($ Pmt-1) & $t$-value & & dlog(ULCt) & $t$-value & & $\operatorname{dlog}($ Pmt $) t$ & $t$-value & & $\operatorname{ar}(1)$ & $t$-value & & DW & R2 & Sample \\
\hline \multirow[t]{2}{*}{ France } & 0.429 & 3.756 & $* * *$ & -0.663 & -4.558 & $* * *$ & 0.098 & 1.710 & * & 0.475 & 5.253 & $* * *$ & -0.117 & -1.131 & & 0.545 & 17.814 & $* * *$ & 0.722 & 4.160 & $* * *$ & 1.760 & 0.962 & 19622007 \\
\hline & $c$ & $t$-value & & $\log ($ Pxt-1) & $t$-value & & $\log (\mathrm{ULCt}-1)$ & $t$-value & & $\log ($ Pmt-1) & $t$-value & & $d \log (U L C t)$ & $t$-value & & $\mathrm{d} \log (\mathrm{Pmt})$ & $t$-value & & DW & R2 & \multicolumn{2}{|c|}{ Sample } & & \\
\hline United Kingdom & 0.043 & 1.592 & & -0.412 & -3.895 & $* * *$ & 0.061 & 2.120 & $* *$ & 0.342 & 4.132 & $* * *$ & 0.179 & 2.378 & $* *$ & 0.575 & 12.748 & $* * *$ & 1.600 & 0.924 & \multicolumn{2}{|c|}{19612007} & & \\
\hline \multirow[t]{2}{*}{ United States } & 0.374 & 3.479 & $* * *$ & -0.352 & -3.238 & $* * *$ & 0.049 & 1.973 & $*$ & 0.223 & 3.214 & $* * *$ & 0.397 & 2.765 & $* * *$ & 0.489 & 11.547 & $* * *$ & 1.929 & 0.913 & \multicolumn{2}{|c|}{19612007} & & \\
\hline & $c$ & t-value & & $d \log (U L C t)$ & $t$-value & & $\operatorname{dlog}(P m t)$ & t-value & & DW & $\mathrm{R} 2$ & \multicolumn{2}{|c|}{ Sample } & & & & & & & & & & & \\
\hline Japan & -0.012 & -4.226 & $* * *$ & 0.313 & 5.610 & $* * *$ & 0.389 & 16.889 & $* * *$ & 2.023 & 0.921 & \multicolumn{2}{|c|}{19612007} & & & & & & & & & & & \\
\hline \multirow[t]{2}{*}{ Australia } & 0.014 & 1.263 & & 0.374 & 1.798 & $*$ & 0.316 & 2.121 & $* *$ & 1.625 & 0.352 & \multicolumn{2}{|c|}{19612007} & & & & & & & & & & & \\
\hline & $c$ & t-value & & $d \log (U L C t)$ & $t$-value & & dlog(ULCt-1) & $t$-value & & $\mathrm{dlog}(\mathrm{Pmt})$ & $t$-value & & DW & R2 & Samp & ple & & & & & & & & \\
\hline \multirow[t]{2}{*}{ Canada } & 0.004 & 0.632 & & 0.620 & 3.209 & $* * *$ & -0.472 & -2.712 & $* *$ & 0.820 & 8.822 & $* * *$ & 1.932 & 0.795 & 1962 & 2007 & & & & & & & & \\
\hline & $c$ & $t$-value & & dlog(ULCt-1) & $t$-value & & $\mathrm{dlog}(\mathrm{Pmt})$ & $t$-value & & DW & $\mathrm{R} 2$ & \multicolumn{2}{|c|}{ Sample } & & & & & & & & & & & \\
\hline \multirow[t]{2}{*}{ Turkey } & -0.013 & -0.395 & & 0.179 & 1.827 & $*$ & 0.868 & 9.972 & $* * *$ & 2.277 & 0.851 & \multicolumn{2}{|c|}{19722007} & & & & & & & & & & & \\
\hline & c & $t$-value & & $d \log (U L C t)$ & t-value & & $\mathrm{dlog}(\mathrm{Pmt})$ & $t$-value & & DW & $\mathrm{R} 2$ & \multicolumn{2}{|c|}{ Sample } & & & & & & & & & & & \\
\hline Mexico & 0.014 & 0.830 & & 0.260 & 2.514 & $* *$ & 0.675 & 9.619 & $* * *$ & 2.112 & 0.925 & \multicolumn{2}{|c|}{19712007} & & & & & & & & & & & \\
\hline Argentina & 0.014 & 0.913 & & 0.107 & 2.858 & $* * *$ & 0.878 & 23.456 & $* * *$ & 2.014 & 0.994 & \multicolumn{2}{|c|}{19712007} & & & & & & & & & & & \\
\hline China & -0.008 & -0.773 & & 0.322 & 2.234 & $* *$ & 1.035 & 14.034 & $* * *$ & 1.772 & 0.905 & \multicolumn{2}{|c|}{19792007} & & & & & & & & & & & \\
\hline \multirow[t]{2}{*}{ India } & 0.022 & 1.259 & & 0.693 & 2.879 & $* * *$ & 0.109 & 1.322 & & 1.711 & 0.342 & \multicolumn{2}{|c|}{19712007} & & & & & & & & & & & \\
\hline & c & $t$-value & & $d \log (U L C t)$ & $t$-value & & $\operatorname{dlog}($ Pxt-1) & $t$-value & & $\mathrm{dlog}(\mathrm{Pmt})$ & $t$-value & & DW & R2 & Samp & ple & & & & & & & & \\
\hline Korea & -0.013 & -1.578 & & 0.336 & 2.911 & $* * *$ & 0.009 & 0.127 & & 0.614 & 9.198 & $* * *$ & 1.703 & 0.886 & 1972 & 2007 & & & & & & & & \\
\hline & c & $t$-value & & $\operatorname{dlog}(U L C t)$ & $t$-value & & $d \log (P m t)$ & $t$-value & & $\operatorname{ar}(1)$ & $t$-value & & DW & R2 & Samp & ple & & & & & & & & \\
\hline South Africa & 0.068 & 1.660 & * & -0.529 & -1.516 & & 0.957 & 6.374 & $* * *$ & 0.357 & 1.995 & $*$ & 1.699 & 0.616 & 1972 & 2007 & & & & & & & & \\
\hline
\end{tabular}

Note: $* * *$, and $* * *$ stand for $10 \%, 5 \%$, and $1 \%$ significance levels respectively 
Table 5: Exports: dependent variable dlog(X)

\begin{tabular}{|c|c|c|c|c|c|c|c|c|c|c|c|c|c|c|c|c|c|c|c|c|c|c|c|}
\hline & $c$ & t-value & & $\operatorname{dlog}(\mathrm{Px} / \mathrm{Pmt})$ & $t$-value & & $\operatorname{dlog}(X t-1)$ & $t$-value & & dlog(Yrwt) & ) $t$-value & & $\operatorname{dlog}(E t)$ & $t$-value & & DW & R2 & Sample & & & & & \\
\hline Euro area-12 & -0.021 & -1.042 & & -1.304 & -4.813 & $* * *$ & * $\quad 0.161$ & 1.460 & & 1.884 & 3.821 & $* * *$ & 0.141 & 1.916 & $*$ & 1.683 & 0.643 & 19712007 & & & & & \\
\hline France & -0.030 & -2.151 & ** & -0.314 & -2.204 & $* *$ & 0.265 & 2.466 & $* *$ & 2.065 & 5.952 & $* * *$ & 0.172 & 2.016 & $* *$ & 1.765 & 0.601 & 19712007 & & & & & \\
\hline & $c$ & $t$-value & & $\mathrm{dlog}((\mathrm{Px} / \mathrm{Pm}) \mathrm{t}-1)$ & $t$-value & & $d \log (Y r w t)$ & $t$-value & & DW & R2 & \multicolumn{2}{|c|}{ Sample } & & & & & & & & & & \\
\hline Germany & 0.000 & 0.002 & & -0.428 & -1.967 & $*$ & 1.779 & 2.911 & $* * *$ & 2.121 & 0.207 & \multicolumn{2}{|c|}{19712007} & & & & & & & & & & \\
\hline & $c$ & $t$-value & & $\mathrm{d} \log (\mathrm{Px} / \mathrm{Pmt})$ & $t$-value & & dlog(Yrwt) & $t$-value & & DW & R2 & \multicolumn{2}{|c|}{ Sample } & & & & & & & & & & \\
\hline Italy & -0.005 & -0.266 & & -0.273 & -1.760 & $*$ & 1.554 & 3.028 & $* * *$ & 1.863 & 0.308 & \multicolumn{2}{|c|}{19712007} & & & & & & & & & & \\
\hline UK & 0.011 & 0.821 & & -0.519 & -3.771 & $* * *$ & 1.057 & 2.885 & $* * *$ & 1.636 & 0.443 & \multicolumn{2}{|c|}{19712007} & & & & & & & & & & \\
\hline Japan & 0.014 & 0.617 & & -0.428 & -4.039 & $* * *$ & 1.293 & 1.984 & $*$ & 2.169 & 0.355 & \multicolumn{2}{|c|}{19712007} & & & & & & & & & & \\
\hline Australia & 0.036 & 1.782 & $*$ & -0.235 & -1.891 & $*$ & 0.472 & 0.779 & & 1.944 & 0.095 & \multicolumn{2}{|c|}{19712007} & & & & & & & & & & \\
\hline & $c$ & $t$-value & & $\operatorname{dlog}(\mathrm{Px} / \mathrm{Pmt})$ & $t$-value & & $d \log (Y r w t)$ & $t$-value & & dlog(Et-1) & $t$-value & & $\operatorname{ar}(1)$ & $t$-value & & DW & R2 & Sample & & & & & \\
\hline US & -0.037 & -1.990 & * & -0.286 & -2.182 & $* *$ & 2.935 & 6.099 & $* * *$ & 0.113 & 2.051 & $* *$ & 0.517 & 3.427 & $* * *$ & 2.315 & 0.727 & 19722007 & & & & & \\
\hline & C & t-value & & $\operatorname{dlog}((\mathrm{Px} / \mathrm{Pm}) \mathrm{t}-1)$ & $t$-value & & $\operatorname{dlog}(X t-1)$ & $t$-value & & dlog(Yrwt) & $t$-value & & DW & R2 & \multicolumn{2}{|c|}{ Sample } & & & & & & & \\
\hline Canada & -0.026 & -1.498 & & -0.558 & -2.774 & $* * *$ & 0.172 & 1.371 & & 2.056 & 4.163 & $* * *$ & 1.648 & 0.495 & \multicolumn{2}{|c|}{19712007} & & & & & & & \\
\hline & c & $t$-value & & dlog(RULCt-1) & $t$-value & & $d \log (Y r w t)$ & t-value & DW & $\mathrm{R} 2$ & Sample & & & & & & & & & & & & \\
\hline Turkey & 0.051 & 0.794 & & -0.557 & -1.903 & $*$ & 0.899 & 0.488 & 2.454 & 0.100 & 1972200 & & & & & & & & & & & & \\
\hline & $c$ & $t$-value & & $\operatorname{dlog}(R U L C t)$ & $t$-value & & dlog(Yrwt) & $t$-value & & $\operatorname{ar}(1)$ & t-value & & DW & R2 & \multicolumn{2}{|c|}{ Sample } & & & & & & & \\
\hline Mexico & 0.005 & 0.160 & & -0.436 & -2.095 & $* *$ & 2.395 & 3.067 & $* * *$ & 0.463 & 2.713 & $* *$ & 1.912 & 0.382 & \multicolumn{2}{|c|}{19722007} & & & & & & & \\
\hline & $c$ & $t$-value & & $\log (X t-1)$ & $t$-value & \multicolumn{3}{|c|}{$\log ($ Px/Pmt-1 t-value } & & $\log (Y r w t-1)$ & $t$-value & \multicolumn{3}{|c|}{ dlog(Px/Pr t-value } & \multicolumn{3}{|c|}{ dlog(Xt-:-value } & $d \log (Y r w t)$ & $t$-value & & DW & R2 & Sample \\
\hline Korea & -42.041 & -3.741 & *** & -0.396 & -4.009 & $* * *$ & -0.198 & -1.713 & $*$ & 1.510 & 3.769 & $* * *$ & 0.256 & 0.964 & & 0.082 & 0.592 & 3.213 & 3.262 & $* * *$ & 1.616 & 0.586 & 19722007 \\
\hline & $c$ & t-value & & $\operatorname{dlog}(\mathrm{Px} / \mathrm{Pmt})$ & t-value & & $\operatorname{dlog}(X t-1)$ & t-value & & $d \log ($ Yrwt $)$ & ) t-value & & DW & $\mathrm{R} 2$ & \multicolumn{2}{|c|}{ Sample } & & & & & & & \\
\hline Argentina & -0.053 & -1.397 & & -0.318 & -1.712 & $*$ & 0.091 & 0.611 & & 3.433 & 3.148 & $* * *$ & 1.715 & 0.257 & \multicolumn{2}{|c|}{19722007} & & & & & & & \\
\hline China & 0.010 & 0.195 & & -1.175 & -3.200 & $* * *$ & 0.396 & 2.556 & $* *$ & 2.584 & 1.742 & $*$ & 1.900 & 0.457 & \multicolumn{2}{|c|}{19802007} & & & & & & & \\
\hline India & 0.084 & 2.371 & $* *$ & -0.253 & -2.364 & $* *$ & 0.185 & 1.165 & & -0.220 & -0.229 & & 1.899 & 0.177 & \multicolumn{2}{|c|}{19722007} & & & & & & & \\
\hline & $c$ & $t$-value & & $\operatorname{dlog}(\mathrm{Px} / \mathrm{Pmt})$ & $t$-value & & $\operatorname{dlog}(Y r w t)$ & $t$-value & & DW & R2 & \multicolumn{2}{|c|}{ Sample } & & & & & & & & & & \\
\hline South Africa & -0.007 & -0.373 & & -0.126 & -1.036 & & 1.101 & 1.876 & $*$ & 1.457 & 0.096 & 19712 & 2007 & & & & & & & & & & \\
\hline
\end{tabular}

Note: $* * *$, and $* * *$ stand for $10 \%, 5 \%$, and $1 \%$ significance levels respectively 
Table 6: Imports: dependent variable $\operatorname{dlog}(\mathrm{M})$

\begin{tabular}{|c|c|c|c|c|c|c|c|c|c|c|c|c|c|c|c|c|c|c|c|c|c|c|c|c|}
\hline & c & $t$-value & & dlog((P/Pm)t-1) & $t$-value & & $d \log (Y t)$ & $t$-value & & DW & R2 & \multicolumn{2}{|c|}{ Sample } & & & & & & & & & & & \\
\hline Euro area-12 & -0.008 & -0.433 & & 0.236 & 1.182 & & 2.035 & 3.450 & $* * *$ & 1.537 & 0.329 & \multicolumn{2}{|c|}{19622007} & & & & & & & & & & & \\
\hline Italy & -0.008 & -0.759 & & 0.233 & 2.390 & $* *$ & 2.136 & 6.818 & $* * *$ & 2.219 & 0.607 & \multicolumn{2}{|c|}{19622007} & & & & & & & & & & & \\
\hline Japan & 0.010 & 0.740 & & 0.255 & 3.299 & $* * *$ & 1.136 & 4.576 & $* * *$ & 1.835 & 0.499 & \multicolumn{2}{|c|}{19622007} & & & & & & & & & & & \\
\hline & c & $t$-value & & $\mathrm{d} \log ((\mathrm{P} / \mathrm{Pm}) \mathrm{t}-1)$ & $t$-value & & $d \log (Y t)$ & $t$-value & & $\operatorname{ar}(1)$ & $t$-value & & DW & R2 & \multicolumn{2}{|c|}{ Sample } & & & & & & & & \\
\hline Germany & 0.009 & 0.990 & & 0.005 & 0.046 & & 1.911 & 7.083 & $* * *$ & 0.283 & 1.848 & $*$ & 1.903 & 0.618 & \multicolumn{2}{|c|}{19632007} & & & & & & & & \\
\hline & $c$ & $t$-value & & $\log (M t-1)$ & $t$-value & & $\log ((P / P m) t-1)$ & $t$-value & & $\log (Y t-1)$ & $t$-value & & $\operatorname{dlog}((\mathrm{P} / \mathrm{Pm}) \mathrm{t})$ & $t$-value & & $d \log (Y t)$ & $t$-value & & DW & $\mathrm{R} 2$ & \multicolumn{2}{|c|}{ Sample } & & \\
\hline France & -2.452 & -4.565 & $* * *$ & -0.292 & -3.932 & $* * *$ & 0.140 & 2.796 & $* * *$ & 0.573 & 4.330 & $* * *$ & 0.069 & 0.989 & & 2.923 & 8.361 & $* * *$ & 2.166 & 0.782 & \multicolumn{2}{|c|}{19612007} & & \\
\hline United Kingdom & -2.954 & -4.748 & $* * *$ & -0.414 & -4.773 & $* * *$ & 0.130 & 3.178 & $* * *$ & 0.769 & 4.814 & $* * *$ & -0.024 & -0.388 & & 1.698 & 8.584 & $* * *$ & 2.142 & 0.739 & \multicolumn{2}{|c|}{19612007} & & \\
\hline United States & -4.610 & -4.639 & $* * *$ & -0.414 & -4.422 & $* * *$ & 0.177 & 3.755 & $* * *$ & 0.826 & 4.554 & $* * *$ & 0.132 & 1.651 & $*$ & 2.341 & 9.783 & $* * *$ & 1.905 & 0.787 & \multicolumn{2}{|c|}{19612007} & & \\
\hline & $c$ & $t$-value & & $\mathrm{dlog}(\mathrm{P} / \mathrm{Pmt})$ & $t$-value & & $\operatorname{dlog}(Y t)$ & $t$-value & & DW & $\mathrm{R} 2$ & \multicolumn{2}{|c|}{ Sample } & & & & & & & & & & & \\
\hline Australia & -0.017 & -0.823 & & 0.558 & 2.964 & $* * *$ & 1.886 & 3.576 & $* * *$ & 2.081 & 0.374 & \multicolumn{2}{|c|}{19612007} & & & & & & & & & & & \\
\hline & $c$ & $t$-value & & $d \log (P / P m t)$ & $t$-value & & $\operatorname{dlog}(Y t)$ & $t$-value & & $d \log (Y t-1)$ & $t$-value & & dlog(Mt-1) & $t$-value & & DW & $\mathrm{R} 2$ & \multicolumn{2}{|c|}{ Sample } & & & & & \\
\hline Canada & 0.000 & -0.008 & & 0.356 & 2.570 & $* *$ & 2.503 & 8.780 & $* * *$ & -1.636 & -4.164 & $* * *$ & 0.424 & 3.369 & $* * *$ & 2.218 & 0.675 & \multicolumn{2}{|c|}{19622007} & & & & & \\
\hline & $c$ & $t$-value & & $d \log (P / P m t)$ & $t$-value & & $\operatorname{dlog}(Y t)$ & $t$-value & & DW & R2 & \multicolumn{2}{|c|}{ Sample } & & & & & & & & & & & \\
\hline Turkey & 0.019 & 0.525 & & 0.546 & 2.363 & $* *$ & 1.684 & 2.714 & $* *$ & 1.809 & 0.390 & \multicolumn{2}{|c|}{19712007} & & & & & & & & & & & \\
\hline & $c$ & $t$-value & & $\mathrm{d} \log ((\mathrm{P} / \mathrm{Pm}) \mathrm{t}-1)$ & $t$-value & & $\operatorname{dlog}(Y t)$ & $t$-value & & $\operatorname{dlog}(E t)$ & $t$-value & & dlog(Et-1) & $t$-value & & DW & R2 & \multicolumn{2}{|c|}{ Sample } & & & & & \\
\hline Mexico & -0.044 & -0.967 & & 0.472 & 2.508 & $* *$ & 2.591 & 3.701 & $* * *$ & -0.236 & -2.397 & $* *$ & 0.368 & 4.112 & $* * *$ & 1.506 & 0.691 & \multicolumn{2}{|c|}{19722007} & & & & & \\
\hline & $C$ & t-value & & $d \log (P / P m t)$ & $t$-value & & $d \log (Y t)$ & $t$-value & & $\operatorname{dlog}(M t-1)$ & $t$-value & & $\operatorname{AR}(1)$ & $t$-value & & DW & $\mathrm{R} 2$ & \multicolumn{2}{|c|}{ Sample } & & & & & \\
\hline Korea & -0.040 & -1.322 & & 0.254 & 1.703 & $*$ & 2.265 & 8.287 & $* * *$ & -0.177 & -1.420 & & 0.390 & 2.003 & $* *$ & 1.890 & 0.722 & \multicolumn{2}{|c|}{19732007} & & & & & \\
\hline & $c$ & $t$-value & & $\log (M t-1)$ & $t$-value & & $\log ((P / P m) t-1)$ & $t$-value & & $\log (\mathrm{Yt}-1)$ & $t$-value & & $\operatorname{dlog}((\mathrm{P} / \mathrm{Pm}) \mathrm{t})$ & $t$-value & \multicolumn{3}{|c|}{ dlog(Mt-1 t-value } & & $\mathrm{d} \log (\mathrm{Yt})$ & $t$-value & & DW & R2 & Sample \\
\hline Argentina & -27.542 & -3.653 & $* * *$ & -0.536 & -4.214 & $* * *$ & 0.400 & 4.148 & $* * *$ & 1.538 & 3.845 & $* * *$ & 0.385 & 4.594 & $* * *$ & 0.105 & 1.807 & $*$ & 3.278 & 11.568 & $* * *$ & 1.762 & 0.917 & 19722007 \\
\hline & $c$ & t-value & & $\log (M t-1)$ & $t$-value & & $\log ((P / P m) t-1)$ & $t$-value & & $\log (Y t-1)$ & $t$-value & \multicolumn{3}{|c|}{ dlog((P/Pm)t-1 t-value } & \multicolumn{3}{|c|}{ dlog(Mt-1 t-value } & & $d \log (Y t)$ & $t$-value & & DW & R2 & Sample \\
\hline China & -10.973 & -4.401 & $* * *$ & -0.656 & -4.055 & $* * *$ & 0.521 & 3.229 & $* * *$ & 0.984 & 4.237 & $* * *$ & -0.650 & -2.569 & $* *$ & 0.333 & 2.192 & $* *$ & 2.690 & 3.869 & $* * *$ & 2.167 & 0.669 & 19802007 \\
\hline & $C$ & $t$-value & & $d \log ((P / P m) t)$ & $t$-value & & $\operatorname{dlog}(Y t)$ & $t$-value & & $\operatorname{LOG}(\mathrm{M}(\mathrm{t}-1)$ & li' t-value & & DW & R2 & Sam & nple & & & & & & & & \\
\hline India & 0.049 & 1.871 & * & 0.546 & 4.984 & $* * *$ & 1.075 & 2.493 & $* *$ & -0.079 & -0.628 & & 1.714 & 0.507 & 197 & 22007 & & & & & & & & \\
\hline & $c$ & $t$-value & & $\log (M t-1)$ & $t$-value & & $\log ((P / P m) t-1)$ & $t$-value & & $\log (Y t-1)$ & $t$-value & & $d \log ((P / P m) t)$ & $t$-value & & $d \log (Y t)$ & $t$-value & & DW & $\mathrm{R} 2$ & Sam & & & \\
\hline South Africa & -2.286 & -2.367 & $* *$ & -0.320 & -6.037 & $* * *$ & 0.320 & 5.518 & $* * *$ & 0.383 & 5.624 & $* * *$ & 0.311 & 2.526 & $* *$ & 4.065 & 12.071 & $* * *$ & 2.179 & 0.864 & 1971 & 12007 & & \\
\hline
\end{tabular}

Note: *, **, and $* * *$ stand for $10 \%, 5 \%$, and $1 \%$ significance levels respectively 
Table 7. The summary of the effects of a 1\%-point increase in the profit share at the national and global level

\begin{tabular}{|c|c|c|c|c|c|c|c|c|c|}
\hline & \multicolumn{7}{|c|}{ The effect of a $1 \%$-point increase in the profit share in only one country on } & \multirow[b]{2}{*}{$\begin{array}{l}\text { \% change in } \\
\text { aggregate demand } \\
\left(F^{*} G\right)\end{array}$} & \multirow{2}{*}{$\begin{array}{c}\text { The effect of a } \\
\text { simulataneous 1\%-point } \\
\text { increase on \% change in } \\
\text { aggregate demand } \\
\text { (including effects of Yrw } \\
\text { and Pm) }\end{array}$} \\
\hline & $\mathrm{C} / \mathrm{Y}$ & $\mathrm{I} / \mathrm{Y}$ & $X / Y$ & $\mathrm{M} / \mathrm{Y}$ & $N X / Y$ & $\begin{array}{c}\text { private excess } \\
\text { demand } / Y\end{array}$ & Multiplier & & \\
\hline & A & B & $\mathrm{C}$ & D & $E(C-D)$ & $F(A+B+E)$ & G & $\mathrm{H}$ & 1 \\
\hline Euro area-12 & -0.439 & 0.299 & 0.057 & 0.000 & 0.057 & -0.084 & 1.590 & -0.133 & -0.245 \\
\hline Germany & -0.501 & 0.376 & 0.096 & 0.000 & 0.096 & -0.029 & 1.076 & -0.031 & - \\
\hline France & -0.305 & 0.088 & 0.036 & -0.162 & 0.198 & -0.020 & 1.388 & -0.027 & - \\
\hline Italy & -0.356 & 0.130 & 0.037 & -0.089 & 0.126 & -0.100 & 1.730 & -0.173 & - \\
\hline United Kingdom & -0.303 & 0.120 & 0.048 & -0.110 & 0.158 & -0.025 & 1.200 & -0.030 & -0.214 \\
\hline United States & -0.426 & 0.000 & 0.006 & -0.031 & 0.037 & -0.388 & 2.080 & -0.808 & -0.921 \\
\hline Japan & -0.353 & 0.284 & 0.028 & -0.026 & 0.055 & -0.014 & 2.407 & -0.034 & -0.179 \\
\hline Canada & -0.326 & 0.182 & 0.063 & -0.203 & 0.266 & 0.122 & 1.214 & 0.148 & -0.269 \\
\hline Australia & -0.256 & 0.174 & 0.049 & -0.223 & 0.272 & 0.190 & 1.410 & 0.268 & 0.172 \\
\hline Turkey & -0.491 & 0.000 & 0.140 & -0.144 & 0.283 & -0.208 & 2.208 & -0.459 & -0.717 \\
\hline Mexico & -0.438 & 0.153 & 0.128 & -0.253 & 0.381 & 0.096 & 1.108 & 0.106 & -0.111 \\
\hline Korea & -0.422 & 0.000 & 0.178 & -0.181 & 0.359 & -0.063 & 1.824 & -0.115 & -0.864 \\
\hline Argentina & -0.153 & 0.015 & 0.014 & -0.178 & 0.192 & 0.054 & 1.381 & 0.075 & -0.103 \\
\hline China & -0.412 & 0.000 & 1.095 & -0.891 & 1.986 & 1.574 & 1.228 & 1.932 & 1.115 \\
\hline India & -0.291 & 0.000 & 0.080 & -0.230 & 0.310 & 0.018 & 2.180 & 0.040 & -0.027 \\
\hline South Africa & -0.145 & 0.129 & 0.000 & -0.506 & 0.506 & 0.490 & 1.487 & 0.729 & 0.390 \\
\hline
\end{tabular}

Note: Column A is calculated based on Equation 2, Column B is based on Equation 4, Column C-E are based on Table E.1 in the appendix.

Column G is based on Table F.1 in the appendix. Column I is calculated as in Equation 7. We examine the Euro area as a single economic unit, and therefore do not include Germany, France, and Italy separately in the calculation of the global interactions in Column I. 


\section{Appendix A: Data sources and definitions}

\section{ws: Adjusted wage share}

\section{EU12, Germany, France, Italy, UK, US, Japan, Canada, Australia: AMECO}

Adjusted wage share $=$ Compensation per employees * number of employed/ GDP at factor costs

\section{Korea, Mexico, Turkey: OECD STAT online}

Adjusted wage share=Compensation per employee*number of employed/value added at basic prices

\section{Argentina:}

1993-2005: Data supplied by Charpe, M. (2011), Adjusted wage share database, ILO/IILS , Geneva. Adjusted wage share= Compensation per employees * number of employed /GDP at basic prices 1970-92 and 2006-07: data supplied by Lindenboim et al (2011);

Unadjusted wage share=Compensation of employees / gdp at basic prices

The adjusted and unadjusted wage share data are linked using \%changes.

\section{China:}

Zhou et al (2010)'s adjusted wage share data calculated using the number of self-employed and national accounts data of China National Statistics Office, reported in Molero Simarro (2011).

\section{India:}

Own calculations based on data supplied by the Ministry of Statistics and Program Implementation in the National Factor Income Summary Tables for 1970-74 and 1980-1999, and estimations supplied by Uma Rani Amara at the ILO/IILS for mixed income for 2000-2007 based on sectoral mixed income shares of 1999 Adjusted wage share methodology 1: labour compensation/(national income at factor cost-mixed revenues) Adjusted wage share methodology 2: labour compensation+Mixed revenues/National Income at factor cost Adjusted wage share average $=$ average of adjusted wage share methodology 1 and 2 (as suggested by Gollin, 2002; Felipe and Sipin, 2004; and Jetin and Kurt 2011) 1975-1979: UN National Account data; unadjusted wage share The unadjusted wage share data for 1975-79 is linked with the adjusted wage share data based on \%changes.

\section{South Africa:}

1989-2004: Data supplied by Matthieu Charpe at the ILO/IILS;

Adjusted wage Share $=$ Compensation per employees $*$ number of employed/ value added at basic prices 1970-88 and 2005-07: UN national accounts, unadjusted wage share 
The two series are linked using \%changes.

\section{Other Data}

For the following variables, data for the OECD countries are from the AMECO database, and data for the other countries are from the World Bank World Development Indicators , unless otherwise stated:

Y: GDP in market prices, real

$\mathbf{Y}_{\mathrm{f}}:$ GDP at factor cost, real

C: Private consumption, real; for Argentina missing data in WDI is linked with the data supplied by

Lindenboim et al (2011) for 1980-1992 based on \% changes.

I: Private Investment, real; for Turkey AMECO data for 1998-2006 is linked with data in State Planning Organisation for 1970-1998; for Korea OECD STAT online; for Mexico Sistema de Cuantas Nacionales de Mexico, Estadisticas historicas de Mexico 2009; for India Central Statistical Organisation; for South Africa The South African Reserve Bank, for Argentina data supplied by Lindenboim et al (2011); for China private investment is calculated as total investment- investment by state owned and collective owned units based on the national accounts data of the National Bureau of Statistics

P: GDP deflator

$\mathbf{P}_{\mathbf{M}}:$ Import price deflator

$\mathbf{P}_{\mathbf{X}}$ : Export price deflator

$\mathbf{X}$ : Exports, real

M: Imports, real

$\mathbf{M}_{\mathrm{ji}}$ : Imports from country j to country I, IMF, Direction of Trade Statistics, 1980-2007 for all countries

E: Exchange rate; average of local currency per dollar, euro, and yen; WDI for all countries $\mathbf{Y}_{\text {rw: }}$ GDP of the rest of world, real; calculated as World GDP (in constant 2000 US\$)-Own GDP (in constant 2000 US\$), WDI, 1970-2007 for all countries

W: Adjusted compensation of employees, real; calculated as $\mathrm{W}=\mathrm{Ws}^{*} \mathrm{Y}_{\mathrm{f}}$

$\pi$ : Adjusted profit share; calculated as $\pi=1-\mathrm{ws}$

R: Adjusted gross operating surplus, real; calculated as $\mathrm{R}=\pi^{*} \mathrm{Y}_{\mathrm{f}}$

rulc: Real unit labour costs; calculated as rulc $={ }_{\mathrm{ws}} * \mathrm{Y}_{\mathrm{f}} / \mathrm{Y}$

ulc: Nominal unit labour costs; calculated as ulc=rulc*P 
Appendix B

Table B.1a Average growth of GDP (\%), developed countries

$\begin{array}{cccccccccc} & \text { Euro area-12 } & \text { Germany } & \text { France } & \text { Italy } & \text { UK } & \text { US } & \text { Japan } & \text { Canada } & \text { Australia } \\ 1961-69 & 5.30 & 4.39 & 5.71 & 5.77 & 2.90 & 4.69 & 10.14 & 5.37 & 5.53 \\ 1970-79 & 3.78 & 3.27 & 4.15 & 4.02 & 2.42 & 3.32 & 5.21 & 4.11 & 3.07 \\ 1980-89 & 2.27 & 1.96 & 2.31 & 2.55 & 2.48 & 3.04 & 4.37 & 3.04 & 3.35 \\ 1990-99 & 2.15 & 2.32 & 1.86 & 1.43 & 2.24 & 3.21 & 1.46 & 2.44 & 3.32 \\ 2000-07 & 2.13 & 1.53 & 2.10 & 1.46 & 2.73 & 2.61 & 1.73 & 2.92 & 3.31\end{array}$

Table B.1b Average growth of GDP, \%, Developing Countries

$\begin{array}{cccccccc} & \text { Turkey } & \text { Mexico } & \text { Korea } & \text { Argentina } & \text { China } & \text { India } & \text { South Africa } \\ 1970-79 & 4.86 & 6.41 & 10.27 & 2.92 & 6.11 & 2.68 & 3.03 \\ 1980-89 & 4.08 & 2.21 & 8.62 & -0.73 & 9.75 & 5.69 & 2.24 \\ 1990-99 & 4.02 & 3.38 & 6.68 & 4.52 & 9.99 & 5.63 & 1.39 \\ 2000-07 & 5.23 & 3.06 & 5.20 & 3.51 & 10.51 & 7.26 & 4.30\end{array}$

Source: See Appendix A 


\section{Appendix C}

For each equation first the long term coefficients (elasticities) are calculated. In the ECM specifications, long-term elasticities are calculated by dividing the statistically significant coefficient of the log-level of the explanatory variable by the negation of the speed of adjustment coefficient (coefficient of the log-level of the dependent variable). If there is no significant cointegration relationship, then based on the difference specifications, long-term elasticities are calculated by adding up the coefficients of the contemporaneous and lagged variable (if they are statistically significant) divided by 1-the coefficient of the lagged dependent variable (if it is statistically significant).

The estimations give us the elasticities. However, as suggested in Stockhammer et al. (2009), we are interested in the marginal (not proportional) effect of a change in $\pi(R / Y)$ on $C$ as a ratio to $\mathrm{Y}$ and I as a ratio to $\mathrm{Y}$ (i.e. $\frac{\partial I / Y}{\partial(R / Y)}$ and $\frac{\partial C / Y}{\partial R / Y}$ ) in order to eventually sum up the effects across different components of demand and find $\frac{\partial Y}{Y}$ as a response to a $1 \%$-point increase in $\mathrm{R} / \mathrm{Y}$.

In the case of investment, $\mathrm{i}_{\pi}$ in Equation 3 is the elasticity of I with respect to $\pi(R / Y)$, hence:

$$
i_{\pi}=\frac{\partial \log I}{\partial \log (R / Y)} \cong \frac{\frac{\partial I}{I}}{\frac{\partial(R / Y)}{(R / Y)}}=\frac{\partial I}{\partial(R / Y)} \frac{R / Y}{I}
$$

Multiplying and dividing Equation D.4 by Y, we obtain

$$
i_{\pi}=\frac{\partial I}{\partial(R / Y)} \frac{Y}{Y} \frac{R / Y}{I}=\frac{\partial I / Y}{\partial(R / Y)} \frac{R}{I}
$$

Hence, the marginal effect of $\mathrm{R} / \mathrm{Y}$ on $\mathrm{I} / \mathrm{Y}$ is

$$
\frac{\partial I / Y}{\partial(R / Y)}=i_{\pi} \frac{I}{R} .
$$


In converting the elasticity to the marginal effect on $\mathrm{I} / \mathrm{Y}$, we use the mean value of $\mathrm{I} / \mathrm{R}$ for the whole sample.

In the case of consumption, the elasticities of $\mathrm{C}$ with respect to $\mathrm{R}$ and $\mathrm{W}$ are $c_{R}$ and $\mathrm{c}_{\mathrm{W}}$ in Equation 1 respectively. Note that in Equation $1 c_{R}$ is estimated for a given $\mathrm{W}$. Same is true for $\mathrm{c}_{\mathrm{W}}$ where the elasticity is estimated for a given R. Hence:

$$
c_{R}=\left.\left.\frac{\partial \log C}{\partial \log R}\right|_{\mathrm{W}} \cong \frac{\frac{\partial C}{C}}{\frac{\partial R}{R}}\right|_{\mathrm{W}}=\left.\frac{\partial C}{\partial R} \frac{R}{C}\right|_{\mathrm{W}}
$$

and

$$
c_{W}=\left.\left.\frac{\partial \log C}{\partial \log W}\right|_{\mathrm{R}} \cong \frac{\frac{\partial C}{C}}{\frac{\partial W}{W}}\right|_{\mathrm{R}}=\left.\frac{\partial C}{\partial W} \frac{W}{C}\right|_{\mathrm{R}}
$$

Dividing and multiplying equations C.4 and C.5 gives

$$
c_{R}=\left.\frac{\partial C / Y}{\partial R / Y} \frac{R}{C}\right|_{W}
$$

and

$$
c_{W}=\left.\frac{\partial C / Y}{\partial W / Y} \frac{W}{C}\right|_{\mathrm{R}}
$$

Calculating the marginal effects gives (for a given level of $\mathrm{W}$ or $\mathrm{R}$ )

$$
\left.\frac{\partial C / Y}{\partial R / Y}\right|_{W}=\left.c_{R} \frac{C}{R}\right|_{W}
$$

and

$$
\left.\frac{\partial C / Y}{\partial W / Y}\right|_{R}=\left.c_{W} \frac{C}{W}\right|_{R}
$$


However, we know that $\mathrm{W} / \mathrm{Y}=1-\mathrm{R} / \mathrm{Y}$; hence for a given $\mathrm{Y}$, i.e. prior to any multiplier effects, whenever there is an increase in $\mathrm{R} / \mathrm{Y}$, there is an equivalent fall in $\mathrm{W} / \mathrm{Y}$, and $\partial \mathrm{W} / \mathrm{Y}=-\partial$ $\mathrm{R} / \mathrm{Y}$. The aggregate effect of an increase of $\mathrm{R} / \mathrm{Y}$ on $\mathrm{C} / \mathrm{Y}$ combines effects from an increasing profit income and falling wage income for an initially constant Y:

$$
\frac{\partial C / Y}{\partial R / Y}=c_{R} \frac{C}{R}-c_{W} \frac{C}{W}
$$

Obviously, the initial change in $\mathrm{C}$ and I will lead to changes in demand and $\mathrm{Y}$, and to further changes in $\mathrm{C}$ and I via the multiplier mechanism as is discussed in Appendix D. In converting the elasticities to the marginal effects, we multiplying the estimated elasticities of $\mathrm{R}$ and $\mathrm{W}$ by the mean values of $\mathrm{C} / \mathrm{R}$ and $\mathrm{C} / \mathrm{W}$ respectively for the whole sample. 


\section{Appendix D}

We can decompose the effects of a change in the profit shares in all countries simultaneously to national and global effects. The total effect is given by

$$
\left[\begin{array}{c}
\frac{d Y_{1}}{Y_{1}} \\
\vdots \\
\frac{d Y_{n}}{Y_{n}}
\end{array}\right]=E_{n x n}\left[\begin{array}{c}
\delta \pi_{1} \\
\vdots \\
\delta \pi_{n}
\end{array}\right]+H_{n x n}\left[\begin{array}{c}
\frac{\delta Y_{1}}{Y_{1}} \\
\vdots \\
\frac{\delta Y_{n}}{Y_{n}}
\end{array}\right]+P_{n x n}\left[\begin{array}{c}
\delta \pi_{1} \\
\vdots \\
\delta \pi_{n}
\end{array}\right]+\left(W_{n x n}\right)\left[\begin{array}{c}
\frac{\delta Y_{1}}{Y_{1}} \\
\vdots \\
\frac{\delta Y_{n}}{Y_{n}}
\end{array}\right]
$$

where $\mathrm{E}$ is a diagonal nxn matrix, where the diagonal elements are the effect of a change in the profit share in country i on private excess demand $(\mathrm{C}+\mathrm{I}+\mathrm{NX})$ in country $\mathrm{i}$, calculated as in Equations 2, 4, and $5^{11}$.

$E_{n \times n}=\left[\begin{array}{cccc}\frac{\delta C}{\frac{Y}{1}_{1}+\frac{\delta I}{Y_{1}}+\frac{\delta N X}{Y_{1}}{ }_{1}} & 0 & \cdots & 0 \\ 0 & \ddots & \vdots & \vdots \\ \vdots & \cdots & \ddots & \vdots \\ 0 & \cdots & \cdots & \frac{\frac{\delta C}{Y_{n}}+\frac{\delta I}{Y_{n}}+\frac{\delta N X}{Y} n}{\delta \pi_{n}}\end{array}\right]$

$\mathrm{H}$ is an nxn diagonal matrix, which shows the effect of an autonomous change in aggregate demand on C, I, and NX in each country and reflects the national multiplier:

$$
H_{n x n}=\left[\begin{array}{cccc}
\frac{\delta C_{1}}{\delta Y_{1}}+\frac{\delta I_{1}}{\delta Y_{1}}-\frac{\delta M_{1}}{\delta Y_{1}} & 0 & \cdots & 0 \\
0 & \ddots & \vdots & \vdots \\
\vdots & \cdots & \ddots & \vdots \\
0 & \cdots & \cdots & \frac{\delta C_{n}}{\delta Y_{n}}+\frac{\delta I_{n}}{\delta Y_{n}}-\frac{\delta M_{n}}{\delta Y_{n}}
\end{array}\right]
$$

${ }^{11}$ To calculate the effect on imports a similar procedure to Equation 5 is followed:

$$
\begin{aligned}
& \frac{\partial(M / Y)}{\partial(w s)}=\left(\frac{\partial M}{\partial P} \frac{\partial P}{\partial(\text { ulc })} \frac{\partial(\text { ulc })}{\partial(\text { rulc })} \frac{\partial(\text { rulc })}{\partial(w s)}\right) \frac{M / Y}{r u l c} \\
& =\left(e_{M P} e_{P} \frac{1}{1-e_{P}} \frac{Y f}{Y}\right) \frac{M / Y}{r u l C} \\
& \text { Then } \frac{\partial\left(\frac{N X}{Y}\right)}{\partial \pi}=\frac{\partial\left(\frac{X}{Y}\right)}{\partial \pi}-\frac{\partial\left(\frac{M}{Y}\right)}{\partial \pi}
\end{aligned}
$$


In our case any change in private demand in country i will lead to a multiplier mechanism in that country, that is it will affect consumption, investment, and imports. The coefficient estimates in Tables 1, 2, and 6 give the elasticities of $\mathrm{C}$, I, and $\mathrm{M}$ with respect to $\mathrm{Y}\left(e_{C Y}, e_{I Y}, e_{M Y}\right.$ respectively).

For the elasticity of $\mathrm{C}$ with respect to $\mathrm{Y}, e_{C Y}$, there is need for further calculation: $e_{C Y}$ is calculated as $e_{C R} \pi+e_{C W}(1-\pi)$, where $e_{C R}$ and $e_{C W}$ are the elasticity of C with respect to profit and wage income respectively. Thus $e_{C Y}$ is a weighted average of the elasticities of $C$ with respect to $\mathrm{R}$ and $\mathrm{W}$, where weights are the shares of $\mathrm{R}$ and $\mathrm{W}$ in $\mathrm{Y}$ (at sample mean).

Again the elasticities have to be converted into partial effects. e.g.:

$$
e_{C Y i}=\frac{\partial \log C_{i}}{\partial \log Y_{i}} \cong \frac{\frac{\partial C_{i}}{C_{i}}}{\frac{\partial Y_{i}}{Y_{i}}}=\frac{\partial C_{i}}{\partial Y_{i}} \frac{Y_{i}}{C_{i}}
$$

Hence,

$$
\frac{\partial C_{i}}{\partial Y_{i}}=e_{C Y_{i}} \frac{C_{i}}{Y_{i}}
$$

Finally $\mathrm{H}_{\mathrm{ii}}=\frac{\partial C_{i}}{\partial Y_{i}}+\frac{\partial I_{i}}{\partial Y_{i}}-\frac{\partial M_{i}}{\partial Y_{i}}=e_{C Y i} \frac{C_{i}}{Y_{i}}+e_{Y_{I} i} \frac{I_{i}}{Y_{i}}-e_{M Y i} \frac{M_{i}}{Y_{i}}$.

If the change in the profit share is isolated to a single country only, then in order to find the total effects of a change in $\pi_{\mathrm{i}}$ on equilibrium aggregate demand in country $i$, private excess demand ( $\mathrm{E}_{\mathrm{ii}}$ has to be multiplied by the standard multiplier:

$$
\frac{d Y_{i} / Y_{i}}{d \pi_{i}}=\frac{\left(\frac{\partial\left(C_{i} / Y\right)}{\partial \pi_{i}}+\frac{\partial\left(I_{i} / Y_{i}\right)}{\partial \pi_{i}}+\frac{\partial\left(N X_{i} / Y_{i}\right)}{\partial \pi_{i}}\right)}{1-\left(\frac{\partial C_{i}}{\partial Y_{i}}+\frac{\partial I_{i}}{\partial Y_{i}}-\frac{\partial M_{i}}{\partial Y_{i}}\right)}=\frac{E_{i i}}{1-H_{i i}}
$$

The numerator is private excess demand, which is the diagonal element in matrix E for country $i$, that is, the change in private demand in country $i$ caused by a change in income 
distribution in country i for a given level of income. The term 1/(1- $\left.\left(\frac{\partial C_{i}}{\partial Y_{i}}+\frac{\partial I_{i}}{\partial Y_{i}}-\frac{\partial M_{i}}{\partial Y_{i}}\right)\right)$ in the Equation (D.7) is the standard national multiplier and is expected to be positive for stability.

The last two matrices in Equation D.1 reflect the global effects when there is a simultaneous change in $\pi$ in all countries. $P$ is an nxn matrix, which shows the effect of a change in a trade partner's profit share, $\pi_{\mathrm{j}}$, on the net exports in each country $\mathrm{i}$

$P_{n x n}=\left[\begin{array}{cccc}0 & \frac{\partial\left(\frac{N X}{Y}\right)_{1}}{\partial \pi_{2}} \frac{M_{21}}{M_{1}} & \cdots & \frac{\partial\left(\frac{N X}{Y}\right)_{1}}{\partial \pi_{n}} \frac{M_{n 1}}{M_{1}} \\ \frac{\partial\left(\frac{N X}{Y}\right)_{2}}{\delta \pi_{1}} \frac{M_{12}}{M_{2}} & 0 & \vdots & \frac{\partial\left(\frac{N X}{Y}\right)_{2}}{\delta \pi_{n}} \frac{M_{n 2}}{M_{2}} \\ \vdots & \cdots & \ddots & \vdots \\ \frac{\partial\left(\frac{N X}{Y}\right)_{n}}{\delta \pi_{1}} \frac{M_{1 n}}{M_{n}} & \frac{\partial\left(\frac{N X}{Y}\right)_{n}}{\delta \pi_{2}} \frac{M_{2 n}}{M_{n}} & \cdots & 0\end{array}\right]$

The diagonal elements of $\mathrm{P}$ are zero; the off-diagonal elements are calculated as:

$P_{i j}=\frac{\partial\left(\frac{N X}{Y}\right)_{i}}{\delta \pi_{j}} \frac{M_{j i}}{M_{i}}=\left(e_{P_{x}} \frac{1}{1-\mathrm{e}_{\mathrm{P}}} \frac{Y f_{j}}{Y_{j}} \frac{1}{r u l c_{j}}\right) \frac{M_{j i}}{M_{i}}\left(\mathrm{e}_{\mathrm{XPi}} \frac{\mathrm{X}_{\mathrm{i}}}{\mathrm{Y}_{\mathrm{i}}}-e_{M P i} \frac{\mathrm{M}_{\mathrm{i}}}{\mathrm{Y}_{\mathrm{i}}}\right)$

The term in the first parentheses shows the effect of a change in the profit share of country $j$ on its export prices (based on the elasticities as discussed above in Equation (5) in section 3). This change is weighted by the share of imports from country $\mathrm{j}$ to country $\mathrm{i}$ in country i's total imports to reflect the effect on country i's overall import prices. The last term calculates the effect of this change in import prices on country i's exports-imports (using the elasticities of $\mathrm{X}$ and $\mathrm{M}$ to $\mathrm{P}_{\mathrm{x}}$ and $\mathrm{P}_{\mathrm{m}}$ respectively), each weighted by the share of exports and imports in GDP.

$\mathrm{W}$ is an nxn matrix, which shows the effects of a change in a trade partner's GDP on the exports of each country:

$W_{n x n}=\left[\begin{array}{cccc}0 & e_{X Y_{r w}} 1 \frac{X_{1}}{Y_{1}} \frac{Y_{2}}{Y_{w}} & \cdots & e_{X Y_{r w}} 1 \frac{X_{1}}{Y_{1}} \frac{Y_{n}}{Y_{w}} \\ e_{X Y_{r w}} 2 \frac{X_{2}}{Y_{2}} \frac{Y_{1}}{Y_{w}} & 0 & \vdots & e_{X Y_{r w}} 2 \frac{X_{2}}{Y_{2}} \frac{Y_{n}}{Y_{w}} \\ \vdots & \cdots & \ddots & \vdots \\ e_{X Y_{r w} n} \frac{X_{n}}{Y_{n}} \frac{Y_{1}}{Y_{w}} & e_{X Y_{r w} n} \frac{X_{n}}{Y_{n}} \frac{Y_{2}}{Y_{w}} & \cdots & 0\end{array}\right]$ 
The diagonal elements of this matrix are zero, and the off-diagonal element, $\mathrm{W}_{\mathrm{ij}}$, is the effect of a change in county j's income on country i's exports (as a ratio to GDP), and is calculated as the elasticity of exports of country i with respect to the GDP of the rest of the world $\left(e_{X Y_{r w}}\right)$ multiplied by the share of exports in GDP in country $\mathrm{i}$ and weighted by the share of country $\mathrm{j}$ in world GDP $\left(\mathrm{Y}_{\mathrm{w}}\right)$. 
Appendix E.

Table E.1: Calculation of the marginal effect of a 1\%-point increase in the profit share on net exports

\begin{tabular}{|c|c|c|c|c|c|c|c|c|c|c|c|c|c|c|}
\hline & & \multicolumn{8}{|c|}{ Exports } & \multicolumn{4}{|c|}{ Imports } & \multirow{2}{*}{$\begin{array}{l}\text { Sum } \\
\partial N X / Y\end{array}$} \\
\hline & & & & & & & & & $\partial X / Y$ & & & & $\partial M / Y$ & \\
\hline & eP & $1 /(1-\mathrm{eP})$ & ePx & eXP & eXRULC & RULC & $\mathrm{Yf} / \mathrm{Y}$ & $X Y$ & $\partial \pi$ & eM.P & eM.RULC & $M / Y$ & $\overline{\partial \pi}$ & $\partial \pi$ \\
\hline & $A$ & B & $\mathrm{C}$ & $\mathrm{D}$ & $E(B * C * D)$ & $\mathrm{F}$ & G & $\mathrm{H}$ & $I\left(-E^{*} G * H / F\right)$ & J & $K\left(A^{*} B^{*} J\right)$ & L & $M\left(-K^{*} G^{*} L / F\right)$ & I-M \\
\hline Euro area (12c & 0.624 & 2.660 & 0.184 & -1.304 & -0.637 & 0.619 & 0.893 & 0.062 & 0.057 & 0.000 & 0.000 & 0.068 & 0.000 & 0.057 \\
\hline Germany & 0.618 & 2.617 & 0.274 & -0.428 & -0.307 & 0.615 & 0.900 & 0.214 & 0.096 & 0.000 & 0.000 & 0.209 & 0.000 & 0.096 \\
\hline France & 0.577 & 2.363 & 0.148 & -0.428 & -0.150 & 0.615 & 0.867 & 0.171 & 0.036 & 0.481 & 0.656 & 0.175 & -0.162 & 0.198 \\
\hline Italy & 0.604 & 2.527 & 0.211 & -0.273 & -0.146 & 0.623 & 0.909 & 0.174 & 0.037 & 0.233 & 0.356 & 0.172 & -0.089 & 0.126 \\
\hline UK & 0.568 & 2.316 & 0.148 & -0.519 & -0.178 & 0.643 & 0.885 & 0.195 & 0.048 & 0.313 & 0.412 & 0.195 & -0.110 & 0.158 \\
\hline US & 0.369 & 1.585 & 0.138 & -0.286 & -0.063 & 0.634 & 0.926 & 0.068 & 0.006 & 0.428 & 0.250 & 0.085 & -0.031 & 0.037 \\
\hline Japan & 0.516 & 2.066 & 0.313 & -0.428 & -0.276 & 0.673 & 0.933 & 0.074 & 0.028 & 0.255 & 0.271 & 0.070 & -0.026 & 0.055 \\
\hline Canada & 0.459 & 1.849 & 0.148 & -0.558 & -0.153 & 0.601 & 0.884 & 0.278 & 0.063 & 0.617 & 0.524 & 0.264 & -0.203 & 0.266 \\
\hline Australia & 0.624 & 2.661 & 0.374 & -0.235 & -0.234 & 0.597 & 0.904 & 0.140 & 0.049 & 0.558 & 0.926 & 0.159 & -0.223 & 0.272 \\
\hline Turkey & 0.481 & 1.927 & 0.179 & -1.613 & -0.557 & 0.459 & 0.937 & 0.123 & 0.140 & 0.546 & 0.506 & 0.139 & -0.144 & 0.283 \\
\hline Mexico & 0.629 & 2.695 & 0.260 & -0.621 & -0.436 & 0.466 & 0.928 & 0.148 & 0.128 & 0.472 & 0.800 & 0.159 & -0.253 & 0.381 \\
\hline Korea & 0.735 & 3.779 & 0.336 & -0.500 & -0.636 & 0.753 & 0.891 & 0.237 & 0.178 & 0.216 & 0.600 & 0.255 & -0.181 & 0.359 \\
\hline Argentina & 0.640 & 2.780 & 0.107 & -0.318 & -0.095 & 0.507 & 0.975 & 0.079 & 0.014 & 0.745 & 1.327 & 0.070 & -0.178 & 0.192 \\
\hline China & 0.771 & 4.376 & 0.322 & -1.945 & -2.741 & 0.504 & 0.867 & 0.232 & 1.095 & 0.795 & 2.683 & 0.193 & -0.891 & 1.986 \\
\hline India & 0.756 & 4.106 & 0.693 & -0.253 & -0.718 & 0.753 & 0.914 & 0.091 & 0.080 & 0.546 & 1.695 & 0.112 & -0.230 & 0.310 \\
\hline South Africa & 0.618 & 2.620 & 0.000 & 0.000 & 0.000 & 0.624 & 0.921 & 0.237 & 0.000 & 1.002 & 1.624 & 0.211 & -0.506 & 0.506 \\
\hline
\end{tabular}

Note: The marginal effect of a $1 \%$-point increase in the profit share on exports (and imports) is $-1 *$ the effect of a $1 \%$-point increase in the wage share on exports

(and imports). Therefore in columns I and $\mathrm{M}$, the values in columns $\mathrm{E}$ and $\mathrm{K}$ are multiplied by -1 . 


\section{Appendix F}

Table F.1 shows the elasticities of $\mathrm{C}$, I, and $\mathrm{M}$ with respect to $\mathrm{Y}$ (as given by the coefficient estimates in Tables 1, 2, and 6) and the national multiplier for each country calculated as described in the diagonal elements of the $\mathrm{H}$ matrix in Appendix E.

Table F.1. Elasticities of C, I, and M with respect to Y and the Multiplier

\begin{tabular}{|l|c|c|c|c|c|}
\hline & $e_{C Y}$ & $\underline{e_{Y I}}$ & $\underline{e_{M V}}$ & $\mathrm{~h}$ & Multiplier \\
\hline Euro area-12 & 0.551 & 1.020 & 2.035 & 0.371 & 1.590 \\
\hline Germany & 0.516 & 0.913 & 1.911 & 0.071 & 1.076 \\
\hline France & 0.494 & 2.050 & 1.963 & 0.280 & 1.388 \\
\hline Italy & 0.539 & 2.610 & 2.136 & 0.422 & 1.730 \\
\hline United Kingdom & 0.579 & 1.311 & 1.859 & 0.167 & 1.200 \\
\hline United States & 0.387 & 3.105 & 1.996 & 0.519 & 2.080 \\
\hline Japan & 0.464 & 1.840 & 1.136 & 0.584 & 2.407 \\
\hline Canada & 0.499 & 1.780 & 1.505 & 0.176 & 1.214 \\
\hline Australia & 0.324 & 2.021 & 1.886 & 0.291 & 1.410 \\
\hline Turkey & 0.457 & 3.343 & 1.684 & 0.547 & 2.208 \\
\hline Mexico & 0.471 & 1.406 & 2.591 & 0.097 & 1.108 \\
\hline Korea & 0.725 & 2.509 & 2.265 & 0.452 & 1.824 \\
\hline Argentina & 0.508 & 0.894 & 2.868 & 0.276 & 1.381 \\
\hline China & 0.539 & 2.031 & 1.501 & 0.185 & 1.228 \\
\hline India & 0.639 & 1.561 & 1.075 & 0.541 & 2.180 \\
\hline South Africa & 0.632 & 1.912 & 1.199 & 0.327 & 1.487 \\
\hline
\end{tabular}

